\title{
Application of Protein-Based Films and Coatings for Food Packaging: A Review
}

\author{
Hongbo Chen ${ }^{1}$, Jingjing Wang ${ }^{1}$, Yaohua Cheng ${ }^{1}$, Chuansheng Wang ${ }^{1,2}$, Haichao Liu ${ }^{3}$, \\ Huiguang Bian ${ }^{1}$, Yiren Pan ${ }^{1}$, Jingyao Sun ${ }^{3,4}$ and Wenwen Han ${ }^{3,5, *}$ \\ 1 College of Electromechanical Engineering, Qingdao University of Science and Technology, Qingdao 266061, \\ China; chenhb@qust.edu.cn (H.C.); 4108030063@mails.qust.edu.cn (J.W.); qustcyh2013@126.com (Y.C.); \\ wangcs07@163.com (C.W.); bhg@qust.edu.cn (H.B.); pyr90hot@163.com (Y.P.) \\ 2 Shandong Provincial Key Laboratory of Polymer Material Advanced Manufactorings Technology, Qingdao \\ University of Science and Technology, Qingdao 266061, China \\ 3 Academic Division of Engineering, Qingdao University of Science \& Technology, Qingdao 266061, China; \\ liuhaichao66mm@qust.edu.cn (H.L.); sunjingyao@mail.buct.edu.cn (J.S.) \\ 4 College of Mechanical and Electrical Engineering, Beijing University of Chemical Technology, \\ Beijing 100029, China \\ 5 National Engineering Laboratory for Advanced Tire Equipment and Key Materials, Qingdao University of \\ Science and Technology, Qingdao 266061, China \\ * Correspondence: hbhanwenwen@qust.edu.cn
}

Received: 12 October 2019; Accepted: 2 December 2019; Published: 9 December 2019

check for updates

\begin{abstract}
As the IV generation of packaging, biopolymers, with the advantages of biodegradability, process ability, combination possibilities and no pollution to food, have become the leading food packaging materials. Biopolymers can be directly extracted from biomass, synthesized from bioderived monomers and produced directly by microorganisms which are all abundant and renewable. The raw materials used to produce biopolymers are low-cost, some even coming from agrion dustrial waste. This review summarized the advances in protein-based films and coatings for food packaging. The materials studied to develop protein-based packaging films and coatings can be divided into two classes: plant proteins and animal proteins. Parts of proteins are referred in this review, including plant proteins i.e., gluten, soy proteins and zein, and animal proteins i.e., casein, whey and gelatin. Films and coatings based on these proteins have excellent gas barrier properties and satisfactory mechanical properties. However, the hydrophilicity of proteins makes the protein-based films present poor water barrier characteristics. The application of plasticizers and the corresponding post-treatments can make the properties of the protein-based films and coatings improved. The addition of active compounds into protein-based films can effectively inhibit or delay the growth of microorganisms and the oxidation of lipids. The review also summarized the research about the storage requirements of various foods that can provide corresponding guidance for the preparation of food packaging materials. Numerous application examples of protein-based films and coatings in food packaging also confirm their important role in food packaging materials.
\end{abstract}

Keywords: protein-based films and coatings; properties; plasticizers; applications for food-packaging; active protein-based films

\section{Introduction}

In order to prolong the shelf life of food and ensure the quality of this food during transportation, food packaging has become increasingly important. The synthetic films occupy a large proportion in the field of food packaging for their good gas and liquid barrier characteristics and mechanical 
properties, low-cost and durability. However, the resistance to degradation of synthetic films made of petroleum results in serious environmental pollution, called white pollution [1].

Thus, the large consumption of raw materials increases the consumption of petroleum resources and disposal problems [2,3]. The use of incineration to deal with the used synthetic films will also generate a lot of heat and toxic gases, which poses a serious threat to human survival and health. In addition, the non-renewable nature of petroleum may make the price of raw materials rise in the future [4]. Recently, 15 countries and regions (including New Zealand, Korea, New York, Chile, France, European Union member states, Australia, India, Britain, Macao, Iceland, Washington State, Brazil and Hainan) have issued bans on plastic products, aiming to curb the increasingly serious marine and ecological and environmental pollution caused by waste plastic products. Most of these countries mention the ban on single-use plastic bags, which are made from nondegradable synthetic films.

All these have accelerated the development of biodegradable food packaging materials made of cheap and readily available raw materials. As the IV generation of packaging, biopolymers, with the advantages of biodegradability, processability, combination possibilities and no pollution to food, have become the leading food packaging materials. Some biopolymers would even act as compost and soil conditioners [5].

As shown in Figure 1, there are three main ways to get biopolymers: (1) Biopolymers (polysaccharides, proteins and lipids) can be directly removed/extracted from biomass;(2) biopolymers (polylactide (PLA) and other polyesters) can be obtained through synthesizing from bioderived monomers; and (3) biopolymers (polyhydroxyalkanoate (PHA), polyhydroxybutyrate (PHB) and poly (3-hydroxybutyrate-co-3-hydroxyvalerate) (PHBV) can be produced directly by microorganisms those are all abundant and renewable [6]. The raw materials used to produce biopolymers are low-cost, and some even come from agrion dustrial waste.

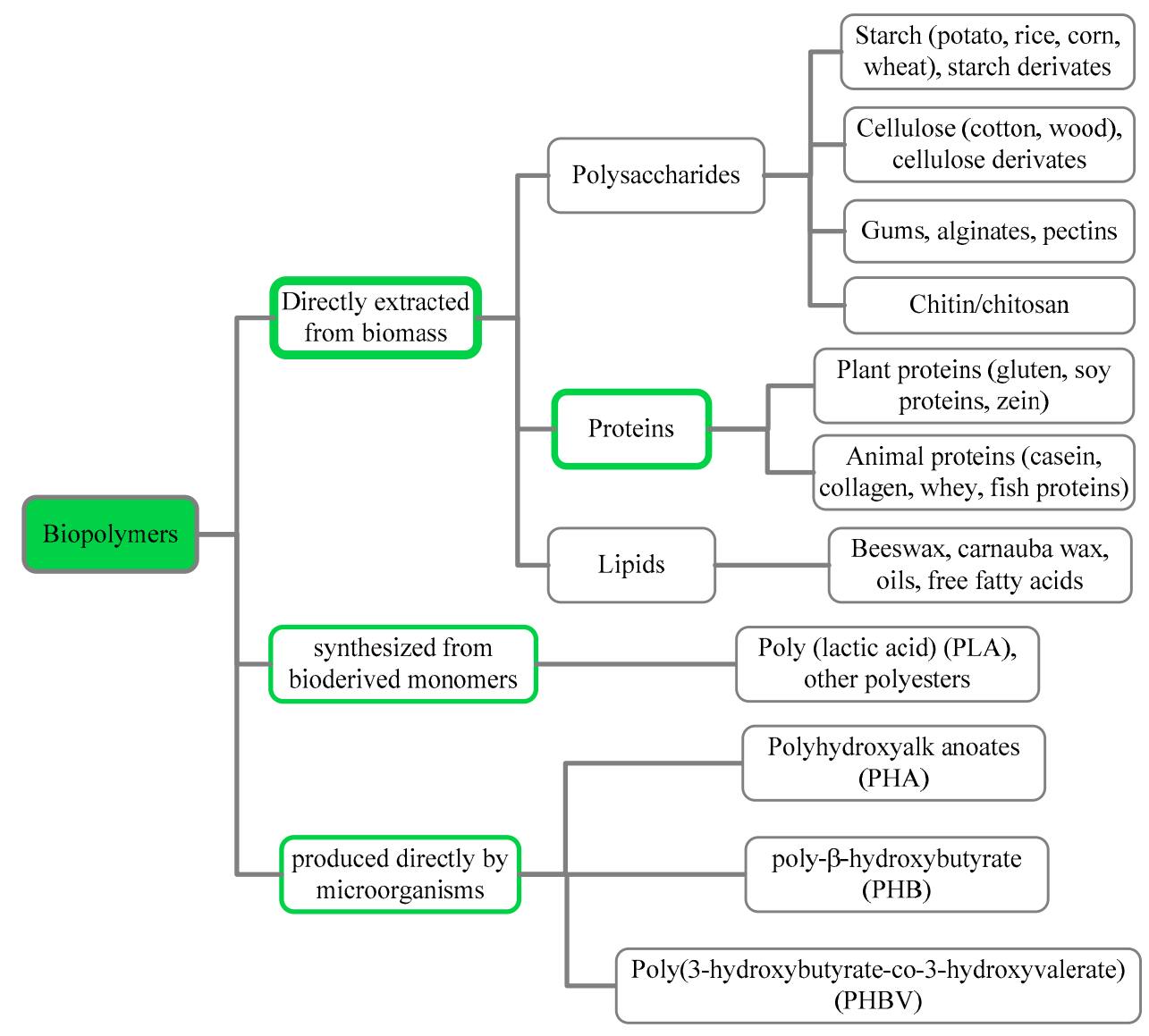

Figure 1. Categories and origins of the biopolymers. 
Biopolymers are not only degradable, but the raw materials are renewable resources. Biopolymers come from nature and eventually return to nature. As shown in Figure 2, the biopolymers used in our life can form a closed cycle, one cycle complete and then go on to the next.

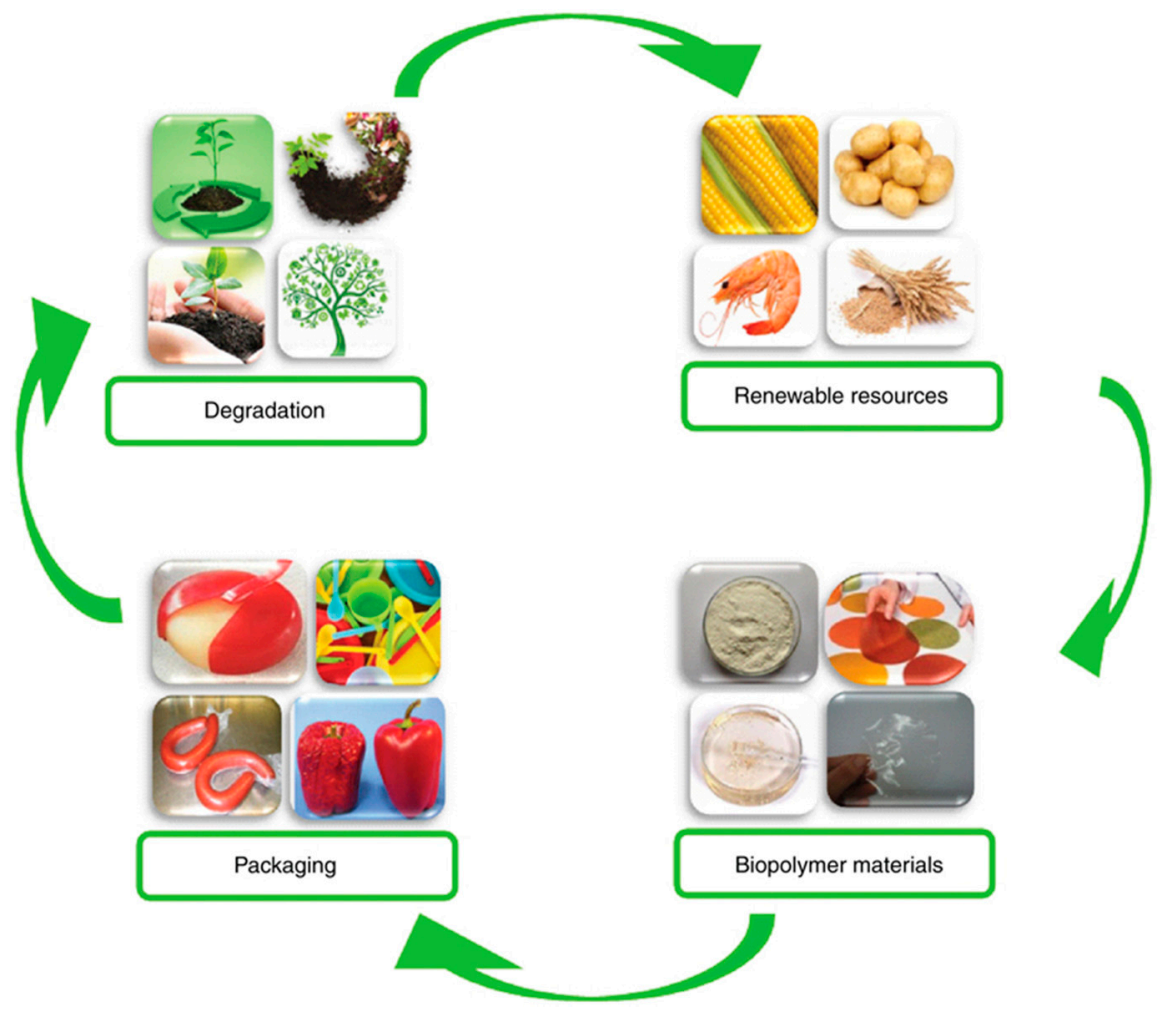

Figure 2. Life Cycle of Biopolymer Packaging Materials. Reproduced with permission from [6].

Biopolymers used as food packaging materials that include films and coatings (films are applied onto the food surface after prepared separately, whereas coatings are formed directly on the food surface) must ensure the health safety, mechanical, thermal and barrier properties and durability. Therefore, in addition to biodegradability, the functionality of the biopolymers-based material is also important [7]. The complex chemical structure and side chains structure provide opportunities for the improvement of biopolymer-based materials through various physical and chemical means, in order to meet the needs in particular situations [8].

\section{Proteins for Biodegradable Films}

The materials used in the preparation of biopolymers are based upon polysaccharides, proteins, or lipids. The main advantages of polysaccharides are abundance, availability, low cost, nontoxicity and thermo-processability [9]. However, because of the hydrophilicity of polysaccharides, polysaccharide-based films have poor barrier properties to water vapor [10]. The biggest advantage of lipids is their hydrophobicity, which can improve the barrier property of materials to water vapor. Lipid films are generally used as coatings because lipid-based films are relatively inelastic [11]. There are some advantages of proteins, such as relative abundance, good film-forming ability, high nutritional value, and so on, which make proteins be used extensively for preparing biodegradable films [12]. Compared to polysaccharides and lipids, protein-based polymers are the most useful, because of the excellent gas barrier properties. The oxygen permeability of soy protein-based films is 260,500 , 540 and 670 times lower than that of low-density methyl cellulose, polyethylene, starch and pectin, respectively. Besides, the mechanical properties of protein-based films are also better than those of polysaccharide-based and lipid-based films [13]. 
Each protein contains about 20 amino acid monomers. Commonly, proteins consist of hundreds of amino acids. The multilevel structures of proteins result in interactions and adhesions between different types of amino acids with different energies at various positions [14]. These structures of proteins can be improved by a variety of physical and chemical methods, for example, mechanical treatment, heat, irradiation, pressure, lipid interfaces, metal ions, acids and alkalis agents [4].

Besides, due to the intrinsic properties of the proteins, they are excellent materials for the preparation of edible films [15-20]. Covering foods with edible films can effectively prevent the loss of moisture and flavors, control gas (oxygen, carbonic dioxide and ethylene) exchange and transport active substances (e.g. antimicrobials, antioxidants, or nutraceuticals) [21].Moreover, it is important that nitrogen sources for those that can act as fertilizer can be provided during the degradation of protein-based films, which is an advantage that non protein-based films do not have [22].

The excellent gas barrier qualities and satisfactory mechanical properties make the protein-based biopolymers one of the most potential materials for food packaging. However, the materials possess poor barrier characteristics for water. Addition of some other biomaterials can reduce the sensitivity of the protein-based biopolymer materials to moisture [23]. Because the cohesive energy density of proteins is strong, the protein-based biopolymers are brittle [24]. The fragility and brittleness exhibited during thermo formation make the protein-based films present poor mechanical properties regarding their processability and end-use application [25]. However, natural and/or biodegradable plasticizers possessing good compatibility with protein-based biopolymers could improve the viscoelasticity and extensibility, so as to solve the above problem [26].

The plasticizer was defined by the council of the International Union of Pure and Applied Chemistry (IUPAC) as "a substance or material incorporated in a material (usually a plastic or elastomer) to increase its flexibility, workability, or distensibility" [27]. In order to form good films, the plasticizers which are low. Volatile small molecules are highly essential to add during the preparation of raw material. The addition of plasticizers into polymeric materials can make the three-dimensional structure modified, the attractive intermolecular forces decrease and the chain mobility and free volumes increase [28]. Plasticizers can enter between the polymeric molecular chains, associating with polymers through physical and chemical reactions, making the extensibility, flexibility, elasticity and distensibility increase, and also causing the mechanical properties, cohesion and rigidity to decrease [29].

The unique structure (based on 20 different monomers) confers a wider range of functional properties to proteins, especially a high intermolecular binding potential [30]. Protein-based films and coatings can form bonds at different positions and offer great potential to form numerous linkages [31]. The molecular weight, as well as the number and positions of the hydroxyl groups of plasticizers, are all variables that affect their plasticizing ability to protein-based polymers [13]. Therefore, the plasticizers that different types of protein-based biopolymers apply are different, and the effects of the same plasticizer on different protein-based biopolymers are also different.

In general, because of the hygroscopicity of biopolymers and plasticizers, the moisture content of films and coatings is affected by the ambient conditions. In addition, as the main solvent of natural biopolymer technology, water makes the $T_{\mathrm{g}}$ reduced, and the free volume of biopolymers is increased. Therefore, water is considered as the most powerful plasticizer for hydrocolloid-based films and coatings [32]. 
Besides water, polyols, monosaccharides, disaccharides and oligosaccharides are the most commonly used plasticizers. Among them, polyols have been reported to be particularly effective for the plasticized hydrophilic polymers [33]. Glycerol (GLY), a typical polyol, has a high hygroscopicity, which can be added to the film-forming solution to improve the brittleness of the films [34]. There are many other materials that can be used as plasticizers for biodegradable films and coatings, such as polyols, including ethylene glycol (EG), tri ethylene glycol (TEG), diethylene glycol (DEG), polyethylene glycol (PEG)and tetra ethylene glycol [30,35-40], along with propylene glycol (PG) [38], xylitol [33,41], sorbitol [30,33-35,38] and mannitol [42]; monosaccharides, including fructose, mannose, glucose and sucrose [30,33,43,44]; fatty acids [45-47]; ethanolamine (EA) [48]; triethanolamine (TEA) [37]; urea [49]; amino acids [50], and so on.

Although there are so many types of plasticizers the most suitable and commonly used plasticizers for different protein-based films are not the same, and the plasticizer selected for the same protein films is also different in different applications. The selection of plasticizers for some kinds of protein-based films in certain applications is mentioned in Table 1.

Table 1. Natural plasticizers used in protein-based films and coatings.

\begin{tabular}{ccc}
\hline System of Application & Plasticizer & References \\
\hline Zein & Oleic and linoleic acids & {$[47]$} \\
\hline Whey protein & GLY and sorbitol & {$[51]$} \\
\hline \multirow{2}{*}{ Wheat gluten } & saturated fatty acids & {$[45]$} \\
\cline { 2 - 3 } & Glycerin & {$[52]$} \\
\hline Caseinate-pullulan & Water and sorbitol & {$[34]$} \\
\hline Whey protein/beeswax emulsion & GLY & {$[53]$} \\
\cline { 2 - 3 } Gelatin & GLY and sorbitol & {$[53]$} \\
\cline { 2 - 3 } & $\begin{array}{c}\text { Sucrose, oleic acid, citric acid, tartaric acid, } \\
\text { malic acid, PEG of different molecular } \\
\text { weights (300, 400, 600, 800, 1500, 4000,10,000 } \\
\text { and 20,000), sorbitol, mannitol, EG, DEG, }\end{array}$ & {$[35]$} \\
\hline \multirow{2}{*}{ TEG, EA, di ethanol amine (DEA) and TEA } & {$[54]$} \\
\cline { 2 - 3 } & GLY & {$[55]$} \\
\cline { 2 - 3 } Bigskin gelatin & Sorbitol & {$[56]$} \\
\hline \multirow{2}{*}{ Bovine gelatin } & Fatty acids & {$[55]$} \\
\cline { 2 - 3 } & Sorbitol & GLY \\
\cline { 2 - 3 }
\end{tabular}

Although the properties of plasticized protein-based films have been improved, there is still a gap between them and synthetic polymer films in terms of functional properties (as shown in Table 2). On the balance of environmental pressure and functional properties, biodegradable materials are more promising, and are gradually replacing the synthetic polymers. At present, in some food packaging applications, biodegradable protein-based materials have met their requirements. Additionally, with the development of research on biodegradable materials, there will be promising potential measures further improving the various properties of protein-based films. The most appropriate protein source, additives and methods will be chosen according to the nature and requirements of the food, the nature and degree of the protection required, the shelf life, the environmental impact, and so on. 
Table 2. Biopolymer and common commercial films, properties reported.

\begin{tabular}{|c|c|c|c|c|c|c|}
\hline Films & Plasticizers & $\begin{array}{l}\text { Opacity } \\
\text { (A.nm) }\end{array}$ & $\begin{array}{c}\text { Mechanical } \\
\text { Properties (TS in } \\
\text { MPa) }\end{array}$ & $\begin{array}{l}\text { Thermal } \\
\text { Properties }\end{array}$ & $\begin{array}{l}\text { Water Vaper } \\
\text { Permeability }\end{array}$ & References \\
\hline \multicolumn{7}{|c|}{ Wheat gluten } \\
\hline Gliadins & Gly $35 \%$ & $\sim 34$ & $\% \mathrm{E}=\sim 390 \mathrm{TS}=\sim 7$ & NR & $\sim 7 \times 10^{11}\left[(\mathrm{gm}) /\left(\mathrm{m}^{2} \mathrm{~s} \mathrm{~Pa}\right)\right]$ & \multirow{2}{*}{ [58] } \\
\hline Glutenins & Gly $35 \%$ & $\sim 101$ & $\% \mathrm{E}=\sim 250 \mathrm{TS}=\sim 1$ & NR & $\sim 4 \times 10^{11}\left[(\mathrm{~g} \mathrm{~m}) /\left(\mathrm{m}^{2} \mathrm{~s} \mathrm{~Pa}\right)\right]$ & \\
\hline \multicolumn{7}{|c|}{ Other Sources } \\
\hline Zein & Gly $40 \%$ & NR & $\% \mathrm{E}=\sim 118 \mathrm{TS}=\sim 4$ & $T_{\mathrm{g}}=\sim 30^{\circ} \mathrm{C}$ & $\sim 4\left(\mathrm{~g} \mathrm{~mm} / \mathrm{m}^{2} \mathrm{~h} \mathrm{kPa}\right)$ & \multirow{3}{*}{ [59] } \\
\hline Kafirin & Gly $40 \%$ & NR & $\% \mathrm{E}=\sim 24 \mathrm{TS}=\sim 1$ & $T_{\mathrm{g}}=\sim 30^{\circ} \mathrm{C}$ & $\sim 8\left(\mathrm{~g} \mathrm{~mm} / \mathrm{m}^{2} \mathrm{~h} \mathrm{kPa}\right)$ & \\
\hline Avenin & Gly $40 \%$ & NR & $\% \mathrm{E}=\sim 40 \mathrm{TS}=\sim 4$ & $T_{\mathrm{g}}=\sim 28^{\circ} \mathrm{C}$ & $\sim 3\left(\mathrm{~g} \mathrm{~mm} / \mathrm{m}^{2} \mathrm{~h} \mathrm{kPa}\right)$ & \\
\hline \multicolumn{7}{|c|}{ Milk } \\
\hline Casein & Gly $50 \%$ & NR & $\% \mathrm{E}=\sim 65 \mathrm{TS}=\sim 2.5$ & NR & $\sim 7(\mathrm{~g} \mathrm{~mm} / \mathrm{m} 2 \mathrm{~h} \mathrm{kPa})$ & [60] \\
\hline \multicolumn{7}{|c|}{ Whey fraction } \\
\hline WPI & Gly $40 \%$ & NR & $\% \mathrm{E}=\sim 33 \mathrm{TS}=\sim 0.9$ & $T_{\mathrm{g}}=\sim 50^{\circ} \mathrm{C}$ & $\sim 8\left(\mathrm{~g} \mathrm{~mm} / \mathrm{m}^{2} \mathrm{~d} \mathrm{kPa}\right)$ & \multirow{2}{*}{ [61] } \\
\hline WPC & Gly $40 \%$ & NR & $\% \mathrm{E}=\sim 18 \mathrm{TS}=\sim 0.7$ & $\mathrm{~T}_{\mathrm{g}}=\sim 43^{\circ} \mathrm{C}$ & $\sim 10\left(\mathrm{~g} \mathrm{~mm} / \mathrm{m}^{2} \mathrm{~d} \mathrm{kPa}\right)$ & \\
\hline \multicolumn{7}{|c|}{ Synthetic polymers } \\
\hline $\begin{array}{l}\text { High Density } \\
\text { Polyethylene } \\
\text { (HDPE) }\end{array}$ & NR & NR & $\% \mathrm{E}=\sim 600 \mathrm{TS}=\sim 54$ & $\mathrm{~T}_{\mathrm{g}}=\sim 80^{\circ} \mathrm{C}$ & $\sim 6\left(\mathrm{~g} / \mathrm{m}^{2} \mathrm{~d}\right)$ & \multirow{4}{*}{ [21] } \\
\hline $\begin{array}{l}\text { Low Density } \\
\text { Polyethylene } \\
\text { (LDPE) }\end{array}$ & NR & NR & $\% \mathrm{E}=\sim 300 \mathrm{TS}=\sim 27$ & $\mathrm{~T}_{\mathrm{g}}=\sim-125^{\circ} \mathrm{C}$ & $\sim 18\left(\mathrm{~g} / \mathrm{m}^{2} \mathrm{~d}\right)$ & \\
\hline $\begin{array}{l}\text { Polypropylene } \\
\text { (PP) }\end{array}$ & NR & NR & $\% \mathrm{E}=\sim 150 \mathrm{TS}=\sim 151$ & $\mathrm{~T}_{\mathrm{g}}=\sim-10^{\circ} \mathrm{C}$ & $\sim 8\left(\mathrm{~g} / \mathrm{m}^{2} \mathrm{~d}\right)$ & \\
\hline $\begin{array}{l}\text { Polyethylene } \\
\text { Terephthalate } \\
\text { (PET) }\end{array}$ & NR & NR & $\% \mathrm{E}=70 \mathrm{TS}=79$ & $\mathrm{~T}_{\mathrm{g}}=\sim 76^{\circ} \mathrm{C}$ & $\sim 21\left(\mathrm{~g} / \mathrm{m}^{2} \mathrm{~d}\right)$ & \\
\hline
\end{tabular}

\subsection{Gluten}

Based on the difference in solubility in aqueous alcohols, gluten proteins are mainly divided into two groups: gliadin and glutenin. The former is soluble and the latter is insoluble [62]. The good film-forming property of gluten is based on its cohesiveness and elasticity.

Gluten films are usually obtained by two methods: One is casting that is done in a thin layer, and the drying process is carried out with aqueous alcoholic after casting, and the other is boiling the protein solutions, and then collecting the films formed on the surface of the solutions or thermos pressing [63-65]. In general, the characteristics of cast films and thermos pressed films are different: the former has higher elongation properties and the latter has stronger rupture resistance. The stress-strain relationship of films obtained through the two methods is also different, indicating that the network structure of proteins is affected by the production process [66].

The most commonly used solvent in film forming solution is water ethanol. The uniformity of the films can be controlled by adjusting the alkaline or acidic conditions of the film-forming solutions. The tensile strength of films produced from alkaline solutions is significantly higher than that of films produced from acidic solutions [67]. In contrast, the properties of films made from alkaline solutions are worse than that of the films produced through ethanol solution [17]. In addition, heating and mechanical mixing also help disperse the gluten and improve the characteristics of the films [68].

The surface of gluten films is shiny, and the films have good oxygen isolation performance, a limited resistance to water vapor and limited mechanical properties [69]. While this is true, various measures can be taken to improve the barrier and mechanical properties of the gluten-based films. The addition of the nonpolar hydrophobic substance (such as mineral oil) into the film-forming dispersion can reduce the water vapor permeability by $25 \%$ compared to the control group [70]. Thermal treatment for the casting films that were obtained through covalent crosslinking of gliadin polypeptide chains could also improve the mechanical properties of the gluten-based films [59]. The gluten-based films can also act as active layers in the form of edible films. Thyme essential oil (TO) 
was added to gluten-based edible films to improve in vitro antioxidant and antimicrobial properties of concentrated samples (as shown in Figure 3) [71]. It can be seen from the figure that with the increase of concentration of $\mathrm{TO}$, the inhibitory effect is enhanced; there is a clear inhibition zone when the concentration of $\mathrm{TO}$ is greater than or equal to $10 \mathrm{wt} \%$; the higher concentration of $\mathrm{TO}$ in films, the more bacteriostatic species and the larger inhibition zone.
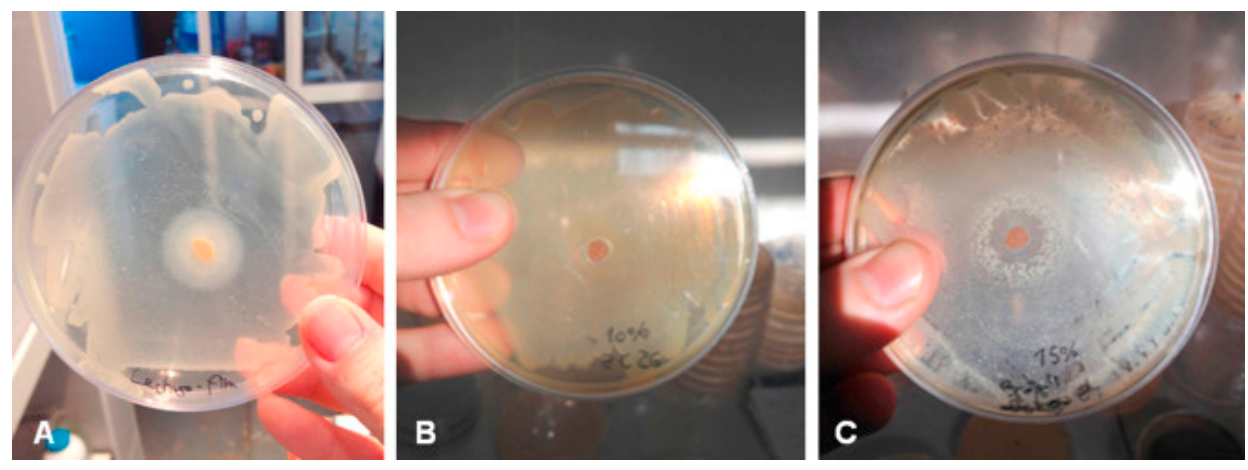

Figure 3. Antimicrobial property of (a) control film with lettuce microflora; (b) $10 \%$ thyme essential oil (TO) film with Escherichia coli and (c) 15\% TO film with broccoli microflora. Reproduced with permission from [71].

\subsection{Soy Proteins}

Their excellent film-forming property made soy proteins extensively studied. Soy protein films have many functional characteristics, such as adhesiveness, cohesiveness, dough, emulsification, water and fat absorption, fiber formation and texturizing capability [72]. Most of the soy protein films are based on soy protein isolate (SPI), that is a highly refined soy protein containing $90 \%$ protein at least, and is made from soy flour, removing the great mass of non-protein components, carbohydrates and fats through isoelectric precipitation [73]. Soy protein films also can be made from soy flour, soymilk and fractioned proteins $[74,75]$. The soy protein films produced from different soy protein fractions exhibit different properties. The increase of the molecular weight of soy proteins made the tensile strength and elongation increase, but did not make the water vapor barrier properties change [75].

Several methods for the film-forming of soy protein were reported, including heating, extruding, spinning, casting and thermally compacting. Heating had been utilized to form soy protein-lipid films in ancient China [72]. A creamy yellow film formed after the soy milk heating to near boiling was removed and dried, and there finally formed the soy protein film [76]. SPI, polyethylene oxide (PEO) and low-density polyethylene (LDPE) could be extruded to produce soy protein films [77]. Spinning was carried out based on an alkaline dope mixed water, SPI and sodium hydroxide solution. The dope was extruded through a spinning nozzle and poured into acetate buffer ( $\mathrm{pH} 4.7$ ), the proteins in the dope coagulated, and a wet film was formed [78]. Mixtures of glycerol and SPI could be formed into soy protein films through thermally compacting at $150-160{ }^{\circ} \mathrm{C}$ and $10 \mathrm{MPa}$ [79]. However, the most commonly used method for preparing soy protein films is casting, that is, drying the thin layers of soy proteins based on film-forming solutions [4].

The film-forming solutions of soy protein films are acid or alkaline, but the characteristics of films produced by alkaline solutions is better than that of films produced by acid solutions $[2,80]$. In addition, different protein concentrations of film forming solutions are required for different film-forming methods. Commonly, the protein concentration is required $4-5 \%$ and $80 \%$ for wet processing and dry processing, respectively [81].

The addition of some substances can affect the film-formation abilities of soy proteins. For example, the addition of sodium dodecyl sulfate (SDS) makes the extendibility of the films substantially increase, while simultaneously the moisture barrier properties improved [28,82]; the addition of carboxy methyl cellulose (CMC) improves the water vapor permeability significantly [83,84]; the 
addition of cysteine makes the number of disulfide bonds of the film-forming solutions and the tensile strength of films increase.

In addition, post-treatments after film formation, such as irradiation and heat curing, can also improve the performance of the soy protein films. The bityrosine can be formed between two protein chains through $\gamma$-irradiation to make the mechanical properties of soy protein films increase. The formation of hydrophobic and disulfide bonds through heat treatment can also make cross-linking promoted [83].

Heat curing made the TS increase from 8.2 to $14.7 \mathrm{MPa}$, but the film elongation decrease from $30 \%$ to $6 \%$ [85]. Coupling thermal treatment with irradiation could make the mechanical properties of soy protein films improve significantly [83].

In general, the hydrophilicity of proteins and plasticizers make the soy protein-based films show poor water vapor barrier properties, good oxygen barrier properties and moderate mechanical properties $[69,85]$.

\subsection{Zein}

Zein, that is a by-product during corn processing, accounts for about $45-50 \%$ of corn proteins [86,87]. Zein proteins are soluble in alcohol, but not in water because of the existence of nonpolar amino acids in zein, which contributes to the water vapor barrier properties of zein films [86,88-91]. However, the films made from pure zein are brittle, yet various measurements proposed by researchers can be carried out to improve the properties of zein films [92,93].

"Wet or solvent process" can be applied to prepare zein-based films, and polyols or fatty acids are commonly chosen as the plasticizers. First, an appropriate solvent is chosen for dissolving zein, plasticizers and some other agents. Then, the film-forming solution is cast on a surface that is flat and nonstick. Finally, the solution is evaporated and a free-standing film can be peeled off from the surface [94]. The zein films can also be prepared through the combination of "wet" and "dry", e.g., stretching or extruding the moldable resin prepared from oleic acid into a film $[95,96]$.

The film-forming solutions for zein include water, methanol, ethanol and acetone, but only water, ethanol and the solution combination of the two, can be used for food packaging [97]. Ethanol hydrous solution is usually chosen as the film-forming solution, and the properties of zein films indicated that the films prepared in acetone were stronger but less flexible than those prepared in ethanol [98].

Physical treatments such as UV irradiation and $\gamma$-radiation can be employed during or after zein films formation to cure the films. The film structures can be affected through the curing method and thus the film properties can be changed accordingly [94,99].

Commonly, zein-based films have a moderate moisture barrier, oxygen barrier and mechanical properties [69].

\subsection{Casein}

Casein, one of the milk proteins, contains four main subunits: kappa-casein, beta-casein, alpha s1-casein and alpha s2-casein that make up 13\%,36\%,38\% and $10 \%$ of the casein composition, respectively $[60,100]$. The unique properties of the four protein fractions affect the film forming ability of casein [101].

Casein can easily form films from aqueous solutions without further processing because of the strong interchain cohesion caused by their random-coil nature and a great number of formed intermolecular hydrogen, hydrophobic and electrostatic bonds [102]. There are such properties of casein, such as biodegradability, high thermal stability, nontoxicity, the ability to bind small molecules and ions, micelle formation capability, all making the protein a good material for biodegradable films [103]. Due to the water solubility, emulsification capability and their high nutritional value, caseins are desirable biomaterials for the preparation of edible films [104-107]. Additionally, casein is readily available [108]. Compared to other proteins, caseins are more insoluble, which make caseinate (mainly sodium caseinate), and this is often used as an alternative to traditional packaging materials. 
Although casein-based films have mentioned above advantages as food packaging, some defects still need to be improved before they can be applied.

A kind of cohesive film matrix produced by the interactive forces between nonpolar and polar amino acid in the structure of casein will shrink during the drying process and then become brittle. The addition of edible plasticizers, e.g., sorbitol or glycerol, can solve the problem (as shown in Figure 4) [109]. However, the plasticizer concentration has a great effect on the tensile properties of films, and the tensile strength would increase with the decrease of concentration.

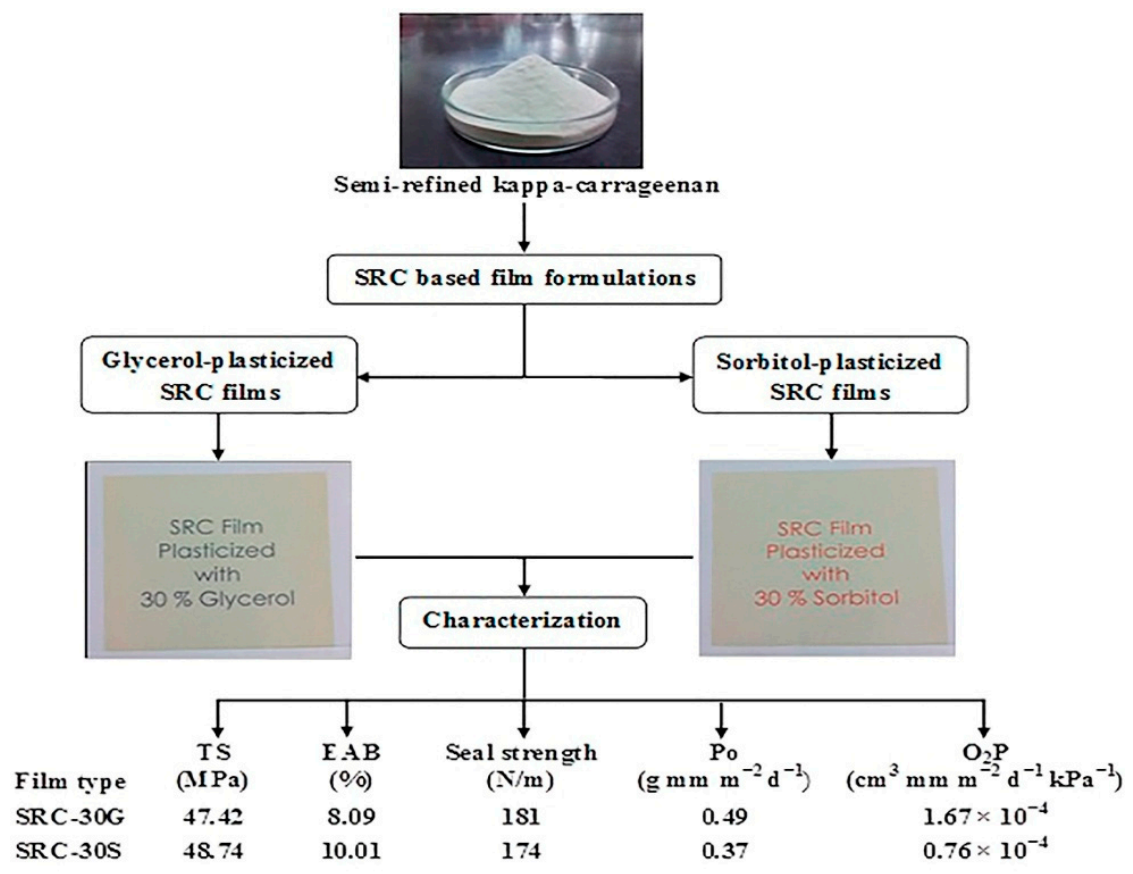

Figure 4. The addition of sorbitol or glycerol could reduce shrinkage during drying and improve the properties of edible films. Reproduced with permission from [109].

Polar amino acids are distributed along the casein chain, which makes the casein-based films have a good barrier effect upon non-polar molecules such as oxygen, and a good protective effect on foods that are prone to oxidation $[21,106]$.

Most casein-based films are soluble in water and highly sensitive to moisture, which seriously affects their mechanical properties and barrier properties. Even though the casein-based films have been plasticized, they still cannot show good mechanical properties and elasticity. The modification of the polymer network through physical and chemical treatments can make the films functionality be improved [105,110]. Glutaraldehyde [111], transglutaminase [112,113], genipin [114-116], tannic acid [117] and wax [107] are typical chemical agents those are used as crosslinkers.

Besides, other methods for the improvements of films prepared from casein and its derivatives have been reported, such as combination with polysaccharides $[118,119]$ or lipid $[109,120,121], \mathrm{pH}$ alteration [122], photo-induced polymerization [123], pulsed light [124], and so on.

\subsection{Whey}

Whey, another milk protein, is a by-product during cheese manufacturing, which makes the protein receive much attention. Whey-based films can be obtained from whey protein concentrates (WPC) and isolates (WPI). The protein contents of the two materials are different, respectively, at least $90 \%$ and $50-80 \%$, and both of the two are rich in cysteine, methionine and sulfur-containing amino acids [125].

The film-forming of whey-based films depends on the thermal denaturation of whey proteins in aqueous solutions. The three-dimensional structure of whey protein can be modified through 
heating, making the internal hydrophobic and SH groups be exposed which have the hydrophobic and intermolecular S-S bonding interactions promoted upon drying [126,127]. The plasticized WPI films can be obtained through heating the whey protein solution with a concentration of $8-12 \%$ at $75-100{ }^{\circ} \mathrm{C}$ for a few minutes [128]. In this way, the irreversible denaturation of whey proteins takes place and the formed films have consistent structure [129]. As long as the amount of solids deposited in each casting surface unit can be kept constant, good whey-based films can be prepared from the WPI solution with a lower concentration (down to $5 \%(w / w)$ ) [130].

Adjusting the denaturing temperature and $\mathrm{pH}$ of the film-forming solution could make the film-forming conditions of WPCs optimized; e.g., when the $\mathrm{pH}$ of film-forming solutions was adjusted to 6.6 through $2 \mathrm{M} \mathrm{NaOH}$ produced solutions, the heating temperature and heating time were controlled at $75{ }^{\circ} \mathrm{C}$ and $30 \mathrm{~min}$, respectively, to ensure uniform film [131].

Some other physical and chemical methods can also improve the properties of the whey-based films; for example ultraviolet (UV) radiation, alkalization and ultrasounds (US). UV treatment applied to film-forming solution at high dose makes most mechanical properties of the whey-based films significantly improved; i.e., the tensile strength, puncture deformation, elastic modulus and puncture strength increased. UV radiation acting directly on the whey-based films makes the color of the films become more yellow, greener and darker, compared to the untreated films. When UV radiation is applied to the film-forming solution, the effects on color are higher [132]. The $\mathrm{pH}$ could influence the properties of the whey proteins and whey-based films. Alkaline $\mathrm{pH}$ promotes protein denaturation, solubilization and unfolding [133]. Whey-based films can be prepared through making the unheated WPI film-forming solutions exposed to strongly alkaline conditions. Compared with the films prepared through heating the WPI film-forming solutions, the films obtained in the strongly alkaline conditions have lower physical strength and slightly weak water barrier properties, but are more likely to disperse in food cooking [134]. When both UV radiation and alkalization are applied in WPC film-forming solutions, in the case wherein the $\mathrm{pH}$ of the film-forming solution is not very high, e.g., 7 or 9, UV radiation makes the films become so strong that the puncture resistance of the films is improved; but in the case of the $\mathrm{pH}$ of film-forming solution being higher, e.g., 11, UV radiation cannot make the mechanical properties of the films improved, because high alkalization in the film-forming solution has made the degree of aggregation and denaturation so intense [135]. US treatments can also make the whey-based films become strong, and the more exposure time, the stronger the films [136].

The whey-based films made with plasticizers are flexible, transparent and bland, and have excellent barrier characteristics for oxygen, oil and aroma. However, the hydrophilic character makes the whey-based films poor moisture barriers. The addition of lipid materials (fat and oils) could increase the hydrophobicity of whey-based films and make the poor moisture barriers improved. The lipid materials commonly used include plant oils [137-139], waxes [140-142], fatty acids [143] and acetylated monoglycerides [144].

\subsection{Gelatin}

The partial degradation of collagen can produce gelatin, and the differences in degree of hydrolysis leads to different molecular weights of gelatin, basically between 65,000 and 300,000 $\mathrm{g} / \mathrm{mol}$. The main ingredients of gelatin include proline, 4 -hydroxyproline and glycine, but different sources cause different contents of these ingredients; for gelatin from pigskin, for example, the contents are 13\%, $9 \%$ and 33\%, respectively [145]. The good film-forming properties, wide existence, low cost, biocompatibility and biodegradability make gelatin become an important raw material for the preparation of biodegradable films [146].

Gelatin films can be obtained through casting from the gelatin aqueous solution. According to the different preparation temperature, it can be divided into cold-cast films and hot-casting films, where the former is prepared under the condition of less than or equal to room temperature, and the latter is prepared at more than $35^{\circ} \mathrm{C}$. The conformational state of the two kinds of gelatin film is different; the former has a spiral structure, and the latter has a statistical coil structure. The latter 
films are more brittle than the former $[147,148]$. he gelatin films also can be obtained by extrusion and blown-extrusion (as shown in Figure 5). The thickness of gelatin films prepared by the above three methods is different, ranging from 357 to $55 \mu \mathrm{m}$, and the thickness of the films obtained by casting are thinner. The tensile strength of films prepared by casting is higher, while the extensibility of films prepared by extrusion is stronger [149].

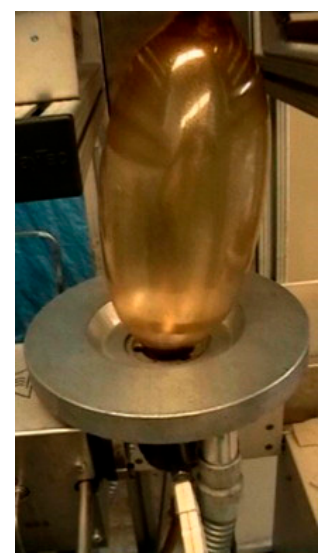

Figure 5. Gelatin films fabricated by blown-extrusion using yucca extract and glycerol. Reproduced with permission from [149].

Gelatin-based films are transparent, oxygen impermeable and the rmoreversible. The melting point of gelatin is close to body temperature, making the gelatin-based films become particularly important raw materials for the preparation of edible films [11]. Edible films based on gelatin have relatively low oxygen permeability and may possess antioxidant and antimicrobial properties by adding some agents like citrus essential oils, carvacrol, and so on [150-152].

\section{Protein-Based Biopolymers Applications for Foods-Packaging}

The choice of food packaging materials depends on the characteristics of packaged food. Different types of foods with different characteristics require different requirements for packaging materials. Besides, the choice of food packaging materials must take environmental factors into consideration, such as relative humidity, temperature and light intensity, to which the foods are exposed during distribution and storage [3].

\subsection{Fruits and Vegetables}

Vegetables and fruits are composed of living tissues that continue to undergo physiological and biochemical changes after harvesting, adversely affecting their quality and shelf life. Respiration and transpiration are the main factors affecting the shelf life of vegetables and fruits. Oxygen is necessary for respiration to take place. Once respiration takes place, the carbohydrate content and weight of vegetables and fruits will decrease, affecting the quality and taste of products $[153,154]$. Water loss by transpiration is the main cause of products' deterioration, making vegetables and fruits lose weight, nutritional value and undergo an appearance change, such as turgidity, wilting, color and texture [15]. Shelf life can be regulated by controlling the respiration and transpiration rates of fresh fruits and vegetables; the lower the rate, the longer the shelf life [155].

In order to have the shelf life of vegetables and fruits extended, the rate of respiration and transpiration must be reduced through controlling relative humidity, temperature, light, surrounding gas $\left(\mathrm{O}_{2}, \mathrm{CO}_{2}\right.$ and ethylene $\left.\left(\mathrm{C}_{2} \mathrm{H}_{2}\right)\right)$, and so on. Some of these factors can be controlled by appropriate food packaging, such as relative humidity, $\mathrm{O}_{2}$ and $\mathrm{CO}_{2}$ concentration.

Different kinds of vegetables and fruits require different relative humidity. For most fruits and vegetables, the optimal relative humidities are $85-95 \%$ and $90-98 \%$, respectively, and the ideal relative 
humidity for some root vegetables is up to $100 \%$ [156]. The relative humidity can be adjusted by the food packaging. Commonly, a high moisture barrier property causes a high relative humidity in the package $[157,158]$.

The oxygen concentration reduced to less than $10 \%$ can make the respiration rate of vegetables and fruits controlled. When the oxygen concentration is excessively low, the anaerobic respiration occurs, the flavors and odors disappear and the anaerobic bacteria grow rapidly. Low concentration of $\mathrm{O}_{2}$, high concentration of $\mathrm{CO}_{2}$, or both, may reduce the production of $\mathrm{C}_{2} \mathrm{H}_{2}$ [159].

However, just regulating the concentration of carbon dioxide does not necessarily lead to an ideal ethylene concentration [160]. Therefore, the gas composition in the food packaging must be strictly controlled. The atmosphere conditions for the preservation of fresh fruits and vegetables are recommended in Table 3.

Table 3. Recommended atmosphere conditions for the preservation of fresh fruits and vegetables [161].

\begin{tabular}{|c|c|c|c|}
\hline Group & Commodity & $\mathrm{CO}_{2}(\%)^{\mathrm{a}}$ & $\mathrm{O}_{2}(\%)^{a}$ \\
\hline \multirow{3}{*}{1} & Potatoes & 0 & 0 \\
\hline & Carrots & 0 & 0 \\
\hline & Beets & 0 & 0 \\
\hline \multirow{6}{*}{2} & Tomatoes & 0 & $3-5$ \\
\hline & Peppers & 0 & $3-5$ \\
\hline & Cucumbers & 0 & $3-5$ \\
\hline & Lettuce & 0 & $2-5$ \\
\hline & Celery & 0 & $2-4$ \\
\hline & Onions(dry) & 0 & $1-2$ \\
\hline \multirow{6}{*}{3} & Pears & $0-5$ & $1-3$ \\
\hline & Lemons & $0-5$ & 5 \\
\hline & Apples & $1-5$ & $2-3$ \\
\hline & Cauliflowers & $2-5$ & $2-5$ \\
\hline & Artichokes & $3-5$ & $2-3$ \\
\hline & Peaches & 5 & $1-2$ \\
\hline 4 & Others & $5-15$ & $1-5$ \\
\hline
\end{tabular}

The protein-based films and coatings were widely used in the preserving of fruits and vegetables. The application of zein coatings to tomatoes makes the color change, softening and weight loss delayed without ethanol production [162]. Applied to apples and pears, the effect of zein coatings on the respiration rate is different, where the respiration rate of the former is decreased, but the respiration rate of the latter is increased. However, the weight losses of the two kinds of fruits are both delayed [163]. The fat deterioration of peanuts can be prevented through coating with a composite of gluten and SPI [164]. Gelatin-based films and coatings are often used to prolong the shelf-life of some kinds of vegetables and fruits, such as carrots [165], calyx from physali [166], cherry tomatoes [167], peppers [168], banana and eggplant [169], fresh-cut melons [170], strawberries [171], pineapple fruit [172], blueberry fruit [173] and minimally processed persimmon [174].

\subsection{Dairy Products}

Dairy products include milk, fermented milk products, processed cheese and cream, being those that provide the human body with numerous nutrients by an easy and quick way in our diet. Due 
to the perishability, the influence of external conditions such as oxygen, light, microorganisms and moisture cannot be ignored.

Oxidation and microbial growth in dairy products can be caused by high oxygen concentration. Nutrient loss, discoloration and off-flavor formation can be brought out by light-induced oxidation, and the presence of moisture accelerates the deterioration of dairy products. These require that the packaging materials of dairy products have low oxygen, moisture permeability and light resistance.

Cheese is one of the most studied and challenging dairy products due to its diversity and differences in characteristics. The instability caused by its biochemically and biologically dynamic nature [175] makes the edible films and coatings widely applied to prolong the shelf life of kinds of cheese.

The selection of proper packaging materials for cheese is challenging, because there are numerous biochemical and microbial processes involved in cheese production, such as lipolysis, oxidation, proteolysis, weight loss and moisture content, which affect flavor, texture and all other physical and chemical properties $[176,177]$.

The barrier properties of packaging materials have a great impact on the shelf life of cheese. Cheese packaging requires gas exchange, because cheese consumes oxygen and releases $\mathrm{CO}_{2}$, but packaging materials must have low oxygen permeability to prevent the growth of harmful microorganisms and the oxidation of fats. Packaging materials should be properly permeated with carbon dioxide, because the presence of carbon dioxide will prolong the growth lag of spoilage microorganisms. Some studies on carbon dioxide permeability show that high and low permeability have different advantages and disadvantages [152]. Cheese should also avoid water evaporation and light-induced oxidation, in order to extend the shelf life of cheese, and avoid the deterioration caused by the oxidation of fat $[153,154]$. Table 4 shows the applications of the protein-based films and coatings for the packaging of dairy products and their potential impact on the quality and shelf life of various cheeses during storage.

Table 4. Applications of protein-based films and coatings for dairy products.

\begin{tabular}{|c|c|c|c|c|c|}
\hline Product, Storage & Film & Added Values & & Effects & References \\
\hline \multirow[t]{2}{*}{$\begin{array}{l}\text { Fresh Kashar cheese, } \\
\quad 4^{\circ} \mathrm{C}, 8 \text { weeks }\end{array}$} & \multirow[t]{2}{*}{$\begin{array}{c}\text { Zein } \\
(\mathrm{Z}) / \text { carnauba } \\
\text { wax }(5 \%) \\
\text { composite films } \\
\text { (ZW) }\end{array}$} & $\begin{array}{l}\text { Lysozyme }\left(0.7 \mathrm{mg} / \mathrm{cm}^{2}\right) \\
\text { (L) }\end{array}$ & L. monocytogenes & $\begin{array}{l}\text { C and F-Z did not change significantly } \\
\text { counts in the first } 28 \text { days, but the } \\
\text { counts of these controls increased } \\
\text { between the 28th and 56th days } \\
\text { All samples containing lysozyme } \\
\text { showed significant reduction } \\
\text { No significant increase occurred in } \\
\text { counts of cheese samples AF-Z-L, } \\
\text { AF-ZW-L, AF-Z-MIX, AF-ZW-MIX }\end{array}$ & \multirow[t]{2}{*}{ [178] } \\
\hline & & $\begin{array}{c}\text { Mixture of lysozyme } \\
\left(0.7 \mathrm{mg} / \mathrm{cm}^{2}\right), \text { catechin } \\
\left(3 \mathrm{mg} / \mathrm{cm}^{2}\right) \text { and gallic } \\
\text { acid }\left(3.0 \mathrm{mg} / \mathrm{cm}^{2}\right) \\
(\mathrm{MIX})\end{array}$ & $\begin{array}{c}\text { Lipid } \\
\text { oxidation/TBARS }\end{array}$ & $\begin{array}{c}\mathrm{C}>\mathrm{F}-\mathrm{Z}=\mathrm{AF}-\mathrm{Z}-\mathrm{L}=\mathrm{AF}-\mathrm{ZW}-\mathrm{L} \text { (no } \\
\text { significant effect) }>\mathrm{AF}-\mathrm{Z}-\mathrm{MIX}= \\
\mathrm{AF}-\mathrm{ZW}-\mathrm{MIX} \text { (significantly lower) }\end{array}$ & \\
\hline \multirow{8}{*}{$\begin{array}{l}\text { Unripened, creamy } \\
\text { Ricotta cheese, } \\
\text { MAP }\left(40 \% \mathrm{CO}_{2}\right. \\
\left.60 \% \mathrm{~N}_{2}\right) \text { at } 4{ }^{\circ} \mathrm{C} \\
30 \text { days }\end{array}$} & \multirow{8}{*}{$\begin{array}{l}\text { Chitosan/whey } \\
\text { protein coating }\end{array}$} & & $\mathrm{pH}$ & $\begin{array}{c}\mathrm{C}=\mathrm{ACO} \text { (decrease, after } 7, \text { and } \\
\text { remained relatively constant until } \\
30 \text { days) }\end{array}$ & \multirow{8}{*}{ [179] } \\
\hline & & & Titratable acidity & $\begin{array}{c}\mathrm{C} \text { (increased) }>\mathrm{ACO} \text { (no significant } \\
\text { differences) }\end{array}$ & \\
\hline & & & LAB & $\mathrm{C}>\mathrm{ACO}$ & \\
\hline & & & $\begin{array}{l}\text { Mesophilic acrobic } \\
\text { bacteria }\end{array}$ & $\mathrm{C}>\mathrm{ACO}$ & \\
\hline & & & $\begin{array}{l}\text { Psychrotrophic } \\
\text { bacteria }\end{array}$ & $\mathrm{C}>\mathrm{ACO}$ & \\
\hline & & & Acidity & Delayed development by ACO & \\
\hline & & & Sensory quality & No effect of ACO & \\
\hline & & & Shelf-life & $\mathrm{C}<\mathrm{ACO}$ & \\
\hline
\end{tabular}


Table 4. Cont.

\begin{tabular}{|c|c|c|c|c|c|}
\hline Product, Storage & Film & Added Values & & Effects & References \\
\hline \multirow{6}{*}{$\begin{array}{l}\text { Cheddar cheese, } \\
5 \pm 1^{\circ} \mathrm{C}, 30 \text { days }\end{array}$} & \multirow{6}{*}{$\begin{array}{l}\text { Casein (CS) } \\
\text { Whey protein } \\
\text { concentrate } \\
\text { (WPC) films }\end{array}$} & & Soluble nitrogen & $\begin{array}{c}\mathrm{C}=\mathrm{F}-\mathrm{CS}=\mathrm{F}-\mathrm{WPC} \\
\left(125.7-151.2 \mathrm{mgN}_{2} / 100 \mathrm{~g}\right)\end{array}$ & \multirow{6}{*}{ [180] } \\
\hline & & & TBARS & $\begin{array}{c}\mathrm{C}(0.01-0.05)>\mathrm{F}-\mathrm{CS}=\mathrm{F}-\mathrm{WPC} \\
(0.01-0.04)\end{array}$ & \\
\hline & & & Titratable acidity & $\mathrm{C}>\mathrm{F}-\mathrm{CS}=\mathrm{F}-\mathrm{WPC}$ & \\
\hline & & & TVC & $\mathrm{C}=\mathrm{F}-\mathrm{CS}=\mathrm{F}-\mathrm{WPC}(7.8-8.1 \log \mathrm{CFU} / \mathrm{g})$ & \\
\hline & & & Yeast, mold & $\begin{array}{c}\mathrm{C}(1.1-1.9 \log \mathrm{CFU} / \mathrm{g})>\mathrm{F}-\mathrm{CS}=\mathrm{F}-\mathrm{WPC} \\
(1.1-1.8 \log \mathrm{CFU} / \mathrm{g})\end{array}$ & \\
\hline & & & Sensory & No significant effect & \\
\hline \multirow{3}{*}{$\begin{array}{l}\text { Semisoft, mini } \\
\text { RedBabybel }{ }^{\circledR} \\
\text { cheese, } 4{ }^{\circ} \mathrm{C} \\
1 \text { week }\end{array}$} & \multirow{3}{*}{$\begin{array}{l}\text { Sodium } \\
\text { caseinate film }\end{array}$} & \multirow{3}{*}{$\begin{array}{c}\text { Nisin }\left(1000 \mathrm{IU} / \mathrm{cm}^{2}\right. \\
\text { surface area } \mathrm{AF})\end{array}$} & *Inoculated product & $\begin{array}{l}\text { was put on active film for analyses } \\
\text { Listeria innocua }\end{array}$ & \multirow{3}{*}{ [181] } \\
\hline & & & $\begin{array}{c}\text { Surface-contaminated } \\
\text { cheese }\end{array}$ & $\mathrm{C}>\mathrm{AF}(1.1 \log )$ & \\
\hline & & & $\begin{array}{l}\text { In-depth contaminated } \\
\text { cheese, mm distance of } \\
\text { film from } \\
\text { contaminated spot }\end{array}$ & $\begin{array}{l}\mathrm{AF}, 3 \mathrm{~mm}(0.25 \mathrm{log})>\mathrm{AF}, 2 \mathrm{~mm} \\
(0.9 \log )>\mathrm{AF}, 1 \mathrm{~mm}(1.1 \log )\end{array}$ & \\
\hline \multirow{3}{*}{$\begin{array}{l}\text { Cheddar cheese, } \\
65 \% \mathrm{RH}, 10^{\circ} \mathrm{C}, \\
5 \text { days }\end{array}$} & $\begin{array}{c}\text { Sodium } \\
\text { caseinate (SC) }\end{array}$ & & $\begin{array}{l}\text { Psychrotrophic } \\
\text { bacteria }\end{array}$ & $\begin{array}{c}\mathrm{C}>\mathrm{F}-\mathrm{SC}=\mathrm{CO}-\mathrm{SC}>\mathrm{F}-\mathrm{CH}=\mathrm{CO}-\mathrm{CH} \\
=\mathrm{F}-\mathrm{SC} / \mathrm{CH}=\mathrm{CO}-\mathrm{SC} / \mathrm{CH}\end{array}$ & \multirow{3}{*}{ [182] } \\
\hline & \multirow{2}{*}{$\begin{array}{l}\text { Chitosan/sodium } \\
\text { caseinate } \\
\text { (SC/CH) films }\end{array}$} & & Yeast & $\begin{array}{c}\mathrm{C}>\mathrm{F}-\mathrm{SC}=\mathrm{CO}-\mathrm{SC}>\mathrm{F}-\mathrm{CH}=\mathrm{CO}-\mathrm{CH} \\
=\mathrm{F}-\mathrm{SC} / \mathrm{CH}=\mathrm{CO}-\mathrm{SC} / \mathrm{CH}\end{array}$ & \\
\hline & & & Molds & $\begin{array}{c}\mathrm{C}>\mathrm{F}-\mathrm{SC}=\mathrm{CO}-\mathrm{SC}>\mathrm{F}-\mathrm{CH}=\mathrm{CO}-\mathrm{CH} \\
=\mathrm{F}-\mathrm{SC} / \mathrm{CH}=\mathrm{CO}-\mathrm{SC} / \mathrm{CH}\end{array}$ & \\
\hline $\begin{array}{l}\text { Fresh Kashar cheese, } \\
10^{\circ} \mathrm{C}, 30 \text { days }\end{array}$ & $\begin{array}{l}\text { Wheat gluten } \\
\text { (WG) methyl } \\
\text { cellulose (MC) } \\
\text { films }\end{array}$ & $\begin{array}{c}\text { Natamycin } 1.2 \mathrm{mg} \\
\text { NA/10 g film solution } \\
2.5 \mathrm{mg} \text { NA/ } 10 \mathrm{~g} \text { film } \\
\text { solution } 3.10 \mathrm{mg} \\
\text { NA/10 g film solution } \\
4.20 \mathrm{mg} \text { NA/ } 10 \mathrm{~g} \text { film } \\
\text { solution }\end{array}$ & A. niger & $\begin{array}{c}\mathrm{C}>\mathrm{F}-\mathrm{MC}(0.6 \log )=\mathrm{AF}-\mathrm{MC} 1(\text { no } \\
\text { significant reduction) }>\text { AF-MC2 }(2 \\
\log )=\mathrm{AF}-\mathrm{MC} 3=\mathrm{AF}-\mathrm{MC} 4 \mathrm{C}>\mathrm{F}-\mathrm{WG} \\
(4.11 \log )>\mathrm{AF}-\mathrm{WG} 1 \text { (completely } \\
\text { inhibited })=\text { AF-MC2 = AF-MC3 }= \\
\text { AF-MC4 }\end{array}$ & [183] \\
\hline
\end{tabular}

Abbreviations: ACO, Active coated sample; AF, active film; C, uncoated sample; CO, coated sample; F, film; log, log $\mathrm{CFU} / \mathrm{g}$ reduction compared to control; MC, moisture content; TBARS, thiobarbituric acid reactive substances; TVC, total viable counts.

\subsection{Meat and Products}

Meat, including fresh meat and cured meat products, is one of the sources of animal protein for most people in the world. Proper packaging allows meat to maintain its protein quality.

For fresh meat, $\mathrm{O}_{2}$ and $\mathrm{CO}_{2}$ concentrations must be in the suitable range. The red oxymyoglobin color can be ensured under high $\mathrm{O}_{2}$ concentration on the product surface, and that can be achieved by using high oxygen permeability packaging materials or Modified Atmosphere Packaging (MAP) with high concentration of $\mathrm{O}_{2}$. However, high levels of oxygen make Gram negative bacteria develop fast on the surface of fresh meat, especially for the ground meats, which have a considerable surface area. The traditional microbial growth can be inhabited under $\mathrm{High}_{2}(70-80 \%)$ coupled with high $\mathrm{CO}_{2}(20-30 \%)$ in MAP, but the lactic acid bacteria, e.g., Carnobacteria spp., can grow slowly in such atmosphere [3]. For some meats with lighter color, the longer shelf life can be achieved by using higher $\mathrm{CO}_{2}$. However, some researches show that off-flavor and discoloration may be formed in poultry when the $\mathrm{CO}_{2}$ concentration is more than $25 \%$ [184].

For cured meat products, the most important problem in storage is to prevent deterioration caused by discoloration. In the presence of light and oxygen, the cured meat products may fade within hours $[185,186]$. The increase of partial pressure of $\mathrm{O}_{2}$ directly causes the acceleration in photo oxidation of the pigment [187]. The reduction in color deterioration may be achieved by the vacuum packaging or MAP under anoxic atmosphere. When there is a very low concentration of residual $\mathrm{O}_{2}$, the packaged cured meat products can be left in the dark for at least four days, the respiration of microorganisms and tissues can consume the residual $\mathrm{O}_{2}$, and then the packaged cured meat products are placed in the display light, which can effectively reduce the discoloration [188,189].

In order to ensure the safety and quality of the meats and products, the biopolymer packaging, which is environmentally friendly, is widely used, and some packaging methods were developed, e.g., 
vacuum, aseptic, modified atmosphere, intelligent, active, and so on. Some application examples of protein-based films for meat and products are shown in Table 5.

Table 5. Protein-based films and coatings for meat and products.

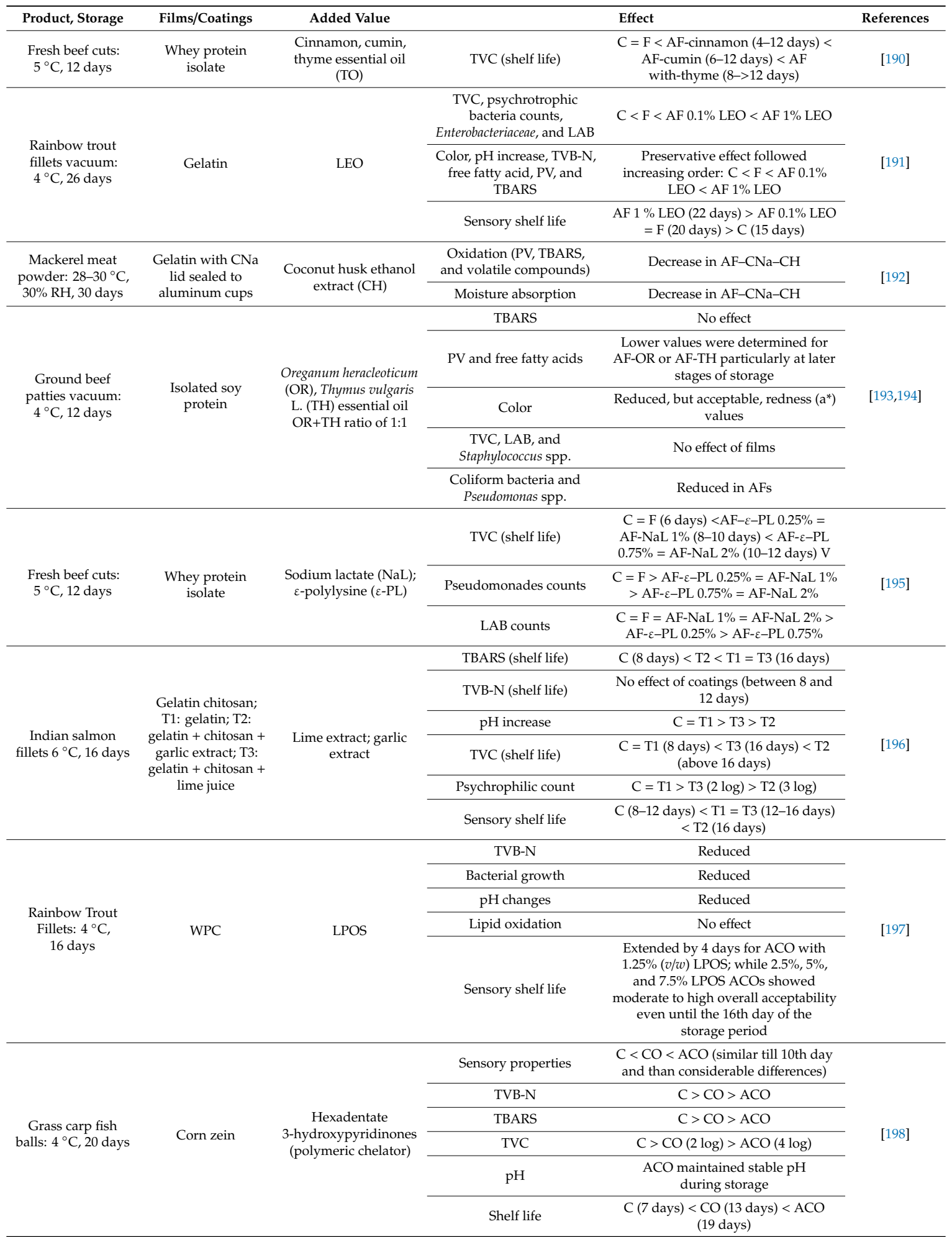

Abbreviations: ACO, Active coated sample; AF, active film; $\mathrm{C}$, uncoated sample; $\mathrm{CNa}$, cloisite $\mathrm{Na}+\mathrm{CO}$, coated sample; F, film; LAB, lactic acid bacteria; LEO, laurel essential oil; LPOS, lacto per oxidase system; PV, peroxide value; TBARS, thio barbituric acid reactive substances; TVB-N, total volatile based nitrogen; TVC, total viable counts. 


\subsection{Frozen Foods}

The deterioration reactions of frozen foods during storage are mainly chemical, including the degradation of vitamins and pigments, destabilization of proteins and oxidation of lipids. Proper packaging can effectively prevent the deterioration of frozen food. Packaging that protects frozen foods from light and oxygen has been shown to reduce the oxidation of pigments and lipids in frozen salmon ides [199] and frozen prawns [200]. When the enzymes have not been removed by blanching (for example, from vegetables), enzyme-catalyzed oxidation may occur without an effective oxygen barrier. Moisture loss caused by the sublimation of the surface of the frozen foods leads to the impairment of visual appearance, unacceptable weight losses of frozen foods and freezer burns. Sublimation of frozen foods can be avoided by sticking packaging materials that are highly impermeable to water vapor tightly to the surface of frozen foods. Obviously, the packaging materials need to be able to withstand low temperatures for a long time. Additionally, the packaging materials should possess grease barrier properties when they are applied in frozen foods with high fat contents [3].

Frozen fish is an important frozen food. Freezing is a good way for fish preservation that can prolong the shelf life of fish with minor changes in product quality if necessary precautions are taken. The freezing process generally has a significant impact on the quality of the final product. During the freezing process, some undesirable modifications may occur, such as lipid oxidation, weight loss, protein denaturation and freeze burning [201,202]. The application of appropriate packaging can prevent some of the undesirable changes.

The whey protein-based coatings applied on Atlantic salmon fillets after freezing make the thaw yield increase, the drip loss decrease and the color parameters change, in comparison with those applied before freezing. The lipid oxidation of salmon fillets is also delayed with the application of protein coatings [203]. The lipid oxidation of salmon fillets can be significantly delayed through the application of ultrasound treatment to the whey protein-based coatings, compared to the samples coated with untreated whey proteins and the uncoated samples [202]. The addition of microbial transglutaminase (MTG) into the heated whey protein-based coatings is also effective for delaying lipid oxidation [204].

The application of whey protein-based coatings with sodium alginate to kilka fish can enhance the product quality and prolong the shelf life during frozen storage up to 6 months. Total bacteria count and Staphylococcus bacteria counts (2/51 and 1/44 log CFU/g) become less than those in control samples (3.21-2.28 log CFU/g). Free fatty acids, peroxide value, thiobarbituric reactive substances (TBRS), $\mathrm{pH}$ and total volatile nitrogen (TVN) in coated samples significantly decrease compared with the control $(p<0.05)$ [205].

In addition, the excellent hydrophilicity of proteins allows the proteins-based films to adhere well to the surface of frozen foods and provides a barrier to the diffusion of oxygen and carbon dioxide without stopping the diffusion of water [203,206,207].

\section{Protein-Based Active Materials}

With the increasing consumer demand for packaged food that is mild, fresh, tasty, convenient and has a long shelf life, the development of new packaging systems is increasingly urgent. In addition, the globalization of markets has led to longer distribution distances, which has created new challenges for the food packaging industry, i.e., longer shelf life and safety and quality issues in transportation.

Active packaging plays an increasingly important role in the food packaging industry due to its unique function. The function of active packaging occurs during the interaction between the product package and the product environment, which not only improves the safety and/or sensory attributes of the product, but also prolongs the shelf life of the products [208-210]. Active packaging refers to the addition of antibacterial and antioxidants agents to food packaging, so that food packaging has antibacterial and antioxidant properties, and the shelf life of food packaged with this packaging can be prolonged [211]. The amphiphilic nature of protein-based films allows it to act as carriers for active compounds to preserve the quality of packaged foods [212]. Additionally, the control of the release of 
active and volatile mass transfer across the film determines the active effect or food quality. Therefore, it is very important to understand the release mechanism of active compounds for the preparation and application of active films.

\subsection{Release Models Applied to Active Packaging}

The affinity, sorption and diffusivity of the protein-based films matrix determine the degree of protection of the active packaging for food quality. Affinity is the result of physicochemical interaction and is the main factor controlling mass transfer. Adsorption is the affinity of different compounds to polymers. Diffusion describes the molecular motion of compounds in the polymer network, depending on a number of factors, such as the structural characteristics or molecular weight of the matrix. The adsorption mechanism involves the migration of small, volatile molecules without interactions, while the diffusion mechanism involves the migration of molecules with large molar volumes. Generally, the low affinity of volatile compounds and the low diffusivity of protein-based films bring out a higher mass transfer efficiency [213,214].

The kinetic studies on the release of active compounds in the films indicate that kinetic data can reveal the ability to release the active compounds to the protein-based films. Therefore, the diffusivity could be obtained from the release kinetics based on Fick's Second Law [213,215]:

$$
\frac{\partial C}{\partial t}=D_{P} \frac{\partial^{2} C}{\partial x^{2}}
$$

where $C$ is the concentration of the active compounds in the film, $t$ is the time and $D_{P}$ is the diffusion coefficient of the active compounds across the film. Through comprehensive consideration and certain model simplification the amount of a substance migrating from a polymer film into food/simulated food could be obtained based on Equation (2) [216]:

$$
M_{F, t}=M_{F, \infty}\left\{1-\sum_{n=1}^{\infty} \frac{2 \alpha(1+\alpha)}{1+\alpha+\alpha^{2} q_{n}{ }^{2}} \exp \left[\frac{-q_{n}{ }^{2} D_{P} t}{L_{P}{ }^{2}}\right]\right\}
$$

where $M_{F, t}$ is the amount of active compounds released into food/simulated food at time $t ; M_{F, \infty}$ is the amount of active compounds released into food/simulated food at equilibrium; $\alpha=V_{F} /\left(V_{P} \cdot K_{P, F}\right)$ and $L_{P}$ is one half the thickness of the film, $V_{F}$ is the volume of food/simulated food, $V_{P}$ is the volume of the films; $K_{P, F}=C_{P} / C_{F}$ is the partition coefficient, $C_{P}$ and $C_{F}$ are the concentration of the substance in films and in food/food stimulants at equilibrium, respectively; and $q_{n}$ are the non-zero positive roots of tan $\left(q_{n}\right)=-q_{n} \cdot \alpha$. However, at the end of the experiment, when the release speed is slow and equilibrium is not reached, Equation (3) can be adopted under the boundary condition of $M_{t} / M_{p}<0.6$ [217]:

$$
\frac{M_{t}}{M_{P}}=\frac{4}{L_{P}}\left(\frac{D t}{\pi}\right)^{1 / 2}
$$

where $M_{t}$ and $M_{p}$ are the mass and initial loading of active substance in the film, $D$ is the diffusion coefficient and the value is estimated according to the slope of the plot of $M_{t} / M_{p}$ versus $t^{1 / 2}$.

The release rate of active compounds is closely related to temperature. The higher the temperature, the faster the release rate. The diffusion coefficient of the active compounds at a certain temperature can be obtained by Equation (4):

$$
D_{P}=D_{0} \exp \left(-\frac{E_{D}}{R T}\right)
$$

where $E_{D}$ is the activation energy of diffusion, $(\mathrm{J} / \mathrm{mol}) ; R$ is the gas constant, its value is $8.314 \mathrm{~J} / \mathrm{mol} / \mathrm{K}$; $T$ is the temperature, $\mathrm{K}$; and $D_{0}$ is the pre-exponential factor, $\mathrm{cm}^{2} / \mathrm{s}$. The activation energies could be obtained through the Arrhenius plot $[215,218]$. After the activation energy is obtained, the diffusion rate of the active compounds could be estimated. The lower activation energy, the more rapid release of active compounds from films [215]. 


\subsection{Antimicrobial Protein-Based Films}

Adding antimicrobial agents to biopolymer films can create an environment inside the packaging that inhibits or delays the growth of microorganisms on the surface of a product, and thus extends the shelf life of the product. By using antibacterial films, the product's surface can maintain a high concentration of active compounds. There are volatile and non-volatile antimicrobial agents, the former evaporating in the package and floating to the headspace of the package, and the latter diffusing into the product. The compatibility and thermal stability of materials should be considered in the selection of antimicrobial agents. There are many kinds of antibacterial agents applied in food packaging, and most of them come from natural resources.

The substances obtained from natural resources that can be used in protein-based films as antimicrobial agents include bacteriocins, Ethylene Diamine Tetraacetic Acid (EDTA), acidulant, antimicrobial enzymes, plant extracts, Essential Oils (EO), Metallic Nano Particles (NP) and so on [219]. There are various antimicrobial mechanisms of $\mathrm{EO}$ for affecting microbial cells, including disrupting enzyme systems, attacking the phospholipid bilayer, and destroying genetic material of bacteria [220]. NPs have many advantages as antimicrobial agents, such as stability, low volatility and the broad spectrum against foodborne pathogens [221,222]. The concentration of NPs used as antimicrobial agents is so low, that the toxicity toward human cells can be negligible [223].

The addition of antibacterial agents not only makes the protein-based films antibacterial, but also affects the performance of the films. Table 6 shows the application examples of some antibacterial agents.

Table 6. Applications of antibacterial agents in protein-based films.

\begin{tabular}{|c|c|c|c|c|}
\hline \multicolumn{2}{|c|}{ Antimicrobial Agents } & Microorganisms & $\begin{array}{l}\text { Performance Impact of } \\
\text { Protein-Based Films }\end{array}$ & References \\
\hline \multirow{2}{*}{ Bacteriocins } & \multirow[b]{2}{*}{$\varepsilon$-polylysine } & $\begin{array}{c}\text { Listeria monocytogenes, } \\
\text { Pseudomonas aeruginosa, } \\
\text { Yarrowialipolytica, Penicillium } \\
\text { commune, Penicillium chrysogenum }\end{array}$ & $\begin{array}{c}\text { The strength was increased } \\
\text { and the permeability was } \\
\text { decreased. }\end{array}$ & [224-227] \\
\hline & & Spoilage flora of fresh beef & $\begin{array}{l}\text { The strength was decreased } \\
\text { and the flexibility was } \\
\text { increased. }\end{array}$ & [228] \\
\hline EDTA & & $\begin{array}{l}\text { L. monocytogenes, Escherichia coli, } \\
\text { Salmonella typhimurium, and } \\
\text { Salmonella enteritidis }\end{array}$ & $\begin{array}{l}\text { There was a minimal effect on } \\
\text { the mechanical properties. }\end{array}$ & {$[224,227,229]$} \\
\hline Acidulant agents & $\begin{array}{l}\text { sodium lactate, potassium } \\
\text { sorbate, and citric, acetic, } \\
\text { malic, lactic, tartaric, sorbic } \\
\text { and paminobenzoicacids }\end{array}$ & $\begin{array}{c}\text { L. monocytogenes, E. coli, Salmonella } \\
\text { gaminara, and Salmonella } \\
\text { typhimurium }\end{array}$ & $\begin{array}{l}\text { The water-content equilibrium, } \\
\text { water vapor permeability, and } \\
\text { extensibility that affected the } \\
\text { glass-transition temperature of } \\
\text { the film were increased. }\end{array}$ & {$[230,231]$} \\
\hline $\begin{array}{l}\text { Antimicrobial } \\
\text { enzymes }\end{array}$ & $\begin{array}{l}\text { Lacto Per Oxidase System } \\
\text { (LPOS) and lysozyme }\end{array}$ & $\begin{array}{c}\text { Shewanellaputrefaciens, } \\
\text { Pseudomonas fluorescens, } L . \\
\text { monocytogenes, Bacillus subtilis, E. } \\
\text { coli, and Staphylococcus aureus }\end{array}$ & $\begin{array}{c}\text { The film structure and } \\
\text { integrity were weakened, but } \\
\text { when the concentration of } \\
\text { active compounds was low, } \\
\text { the film's properties would } \\
\text { not be affected. }\end{array}$ & {$[102,232-234]$} \\
\hline EOs & $\begin{array}{l}\text { lemon peel, Zataria } \\
\text { multiflora Boiss, orange } \\
\text { leaves, cinnamon, thyme, } \\
\text { clove and oregano }\end{array}$ & $\begin{array}{l}\text { Pathogens and food-spoilage } \\
\text { microorganisms }\end{array}$ & $\begin{array}{l}\text { The permeability, water } \\
\text { solubility, strength and } \\
\text { extensibility were decreased. }\end{array}$ & [235-243] \\
\hline \multirow{3}{*}{$\begin{array}{l}\text { Commercially } \\
\text { derived } \\
\text { antimicrobials }\end{array}$} & $\begin{array}{c}\text { ArticoateDLP-02, Artimex } \\
\text { 152/NL, sodium octanoate, } \\
\text { and Auranta FV }\end{array}$ & $\begin{array}{l}\text { E. coli, Bacillus cereus, } \text { P. fluorescens, } \\
\text { S. aureus, and microflora from beef } \\
\text { steaks [32] }\end{array}$ & $\begin{array}{l}\text { The protein network was } \\
\text { destabilized. }\end{array}$ & [244] \\
\hline & $\begin{array}{l}\text { Ethyl-N } \alpha \text {-dodecanoyl-L- } \\
\text { Arginate hydrochloride } \\
\text { (LAE) }\end{array}$ & L. monocytogenes and E. coli & $\begin{array}{l}\text { A barrier against carbon } \\
\text { dioxide and oxygen was } \\
\text { formed. }\end{array}$ & [218] \\
\hline & Prunin Laurate ester (PL) & $\begin{array}{l}\text { L. monocytogenes, S. aureus, and B. } \\
\text { cereus }\end{array}$ & $\begin{array}{l}\text { The functional properties were } \\
\text { not affected. }\end{array}$ & [245] \\
\hline NPs & $\begin{array}{l}\text { Silver Nano Particles } \\
\text { (AgNP) }\end{array}$ & foodborne pathogens & $\begin{array}{l}\text { The barrier and mechanical } \\
\text { properties were enhanced, but } \\
\text { there might be potential } \\
\text { toxicity. }\end{array}$ & [246] \\
\hline
\end{tabular}




\subsection{Antioxidant Protein-Based Films}

The addition of antioxidants to packaging materials can delay the oxidation of lipids and reduce odors, discoloration and vitamin loss of food. Besides, compared with adding antioxidants directly to food, the technique has several advantages, such as less antioxidant dose and antioxidant activity concentrating on more sensitive product surfaces by migration from the film to the food.

The use of this antioxidant film extends the shelf life of the product and omits additional processing steps such as mixing, soaking or spraying [209,247].

Antioxidants used in food packaging are either natural antioxidants or derived from natural resources. Synthetic antioxidants have been banned from food packaging because of their safety concerns. Similar to the antibacterial protein-based films, the addition of antioxidants not only changes the antioxidant property of the protein-based films, but also changes some performance of the protein-based films.

Ascorbic acid [232], $\alpha$ - tocopherol [234,248,249], coumarin [250] and ferulic acid [251] are natural antioxidants. Among them, $\alpha$-tocopherol has the greatest influence on the properties of the protein-based films. The steric effect of $\alpha$-tocopherol is so great, that the diffusion of gases through the protein chains is limited. In other words, the mechanical and barrier properties of the protein-based film can also be improved by the addition of antioxidant compounds.

Besides, there are some natural extracts that act as antioxidants, which are an important part of antioxidants obtained from natural resources. The selection of natural extracts depends on the characteristics of the packaged product and the requirements of storage. Myofibrillar-protein films coupled with Catechin-Kradon leaf extracts could effectively make the lipid oxidation and the formation of the metmyoglobin of refrigerated fish slices suppressed [251]. In addition to improving the antioxidant property of the films, natural extracts could have a certain effect on the film performance. The addition of Red-grape extracts into soy-protein films made the flexibility and the water vapor permeability of the casted films to be improved. The reason was that the redistribution of hydrogen interactions was induced and the interactions of protein-protein were replaced by those of protein-polyphenol, which are particularly noticeable when compression molding is applied. At the same time, because of the strong interactions between the phenolic compounds and the protein matrix, more antioxidants were released from the compression-molded films [252]. The addition of Caesalpiniaspinosa and Caesalpiniadecapetala extracts into gelatin films would decrease strength and increase flexibility [253]. The incorporation of green tee extracts into gelatin films made the flexibility, water vapor permeability and water solubility decrease and the strength increase [254]. However, when black-tea, green-tea and oolong-tea extracts as antioxidants were incorporated into protein-based films, themselves produced from distiller dried grains for preventing the lipid oxidation of pork meat during storage, the flexibility and the strength of the films were changed, the former increased and the latter decreased [255]. Adding mango seed-kernel extracts into the protein-based films produced from SPI and fish gelatin makes the antioxidant activity and strength increase, while the flexibility and water solubility decrease $[20,247]$. The addition of murta-leaf extracts into gelatin films also changed the properties of the films, and the higher the polyphenol content, the more the mechanical properties decreased [256].

EOs are bioactive compounds formed by a mixture of various substances, with a wide range of chemical components, obtained from plant secondary metabolism. In addition to their traditional roles as natural food additives and aromatic agents, they can also be used as antibacterial agents and antioxidants $[257,258]$. The typical antioxidants in EOs include clove [242,259], marjoram and coriander [242], Zataria multiflora Boiss [260], ginger [261], Morinda citrifolia [262], orange leaves [237], cinnamon [238,239], garlic [263], and so on. There are also many studies and applications of adding EOs to protein-based films for delaying the oxidation of food. The delay of lipid oxidation of sliced cheddar cheese can be achieved by adding coriander, marjoram or clove EOs to gelatin-based films [242]. The shelf life of fresh shrimp can be prolonged by covering gelatin-based films incorporated with orange leaf EOs [238], that of fish fillet can be prolonged by covering WPC coating incorporated with 
cinnamon EOs [239], and that of smoked salmon during refrigerated storage can be prolonged by covering composite protein-based films incorporated with clove EOs [259].

\section{Conclusions}

The good film-forming properties of proteins make the protein-based films become one of the key points in the research of food packaging materials. Due to different physical and chemical properties, the film-forming ability of each protein is slightly different. The preparation methods of various protein-based films are similar. The corresponding plasticizers are usually added to improve the elasticity and viscoelasticity of protein-based films in the production process. In general, the protein-based films have moderate mechanical properties and good oxygen barrier properties, but they are sensitive to water. Some physical or chemical post-treatment methods can be applied to make the properties of protein-based films improved for specific applications.

Each type of food has specific storage requirements, which requires packaging materials to meet specific storage conditions for specific foods. Protein-based biopolymer materials can meet the requirements of various food packaging materials through modification. Additionally, the nutrition and biodegrade ability of proteins makes themselves become one of the best choices of food packaging materials. The research about the relations among the function, structure and composition of protein-based films will guide the methods and schemes of film modification, so that the protein-based films suitable for food packaging with better properties will be prepared.

Active packaging provides a guarantee for the rapid development of the functional food market. The active (antioxidant and antimicrobial) protein-based films, those selected based on the food characteristics and storage requirements, can effectively inhibit or delay the growth of microorganisms and the oxidation of lipids, thus ensuring food safety and prolonging the shelf life of food.

Author Contributions: Conceptualization, C.W. and J.S.; writing-original draft preparation, H.C., Y.C. and H.L.; writing-review and editing, W.H., J.W. and Y.P.; funding acquisition, H.B.

Funding: This research was supported by the National Natural Science Foundation of China (No. 51875297); the Natural Science Foundation of Shandong Province (No. ZR2019BEE056 and ZR2016XJ003), Qingchuang Technology Plan (No. 2019KJB007), Key Research and Development Plan of Shandong Province (No.2019GGX102018), the Fundamental Research Funds for Central Universities (No. JD1910), and the Talents Introduction Project in Beijing University of Chemical Technology (No. buctrc201909).

Conflicts of Interest: The authors declare no conflict of interest.

\section{References}

1. Haosagul, S.; Boonyawanich, S.; Pisutpaisal, N. Biomethane Production from co-fermentation of agricultural wastes. Int. J. Hydrogen Energy 2019, 44, 5355-5364. [CrossRef]

2. Siracusa, V.; Lotti, N. Biobased Plastics for Food Packaging. In Reference Module in Food Science; Elsevier: Amsterdam, The Netherlands, 2018.

3. Petersen, K.; Væggemose Nielsen, P.; Bertelsen, G.; Lawther, M.; Olsen, M.B.; Nilsson, N.H.; Mortensen, G. Potential of biobased materials for food packaging. Trends Food Sci. Technol. 1999, 10, 52-68. [CrossRef]

4. Zhang, H.; Mittal, G. Biodegradable protein-based films from plant resources: A review. Environ. Prog. Sustain. Energy 2010, 29, 203-220. [CrossRef]

5. Tharanathan, R.N. Biodegradable films and composite coatings: Past, present and future. Trends Food Sci. Technol. 2003, 14, 71-78. [CrossRef]

6. Popović, S.Z.; Lazić, V.L.; Hromiš, N.M.; Šuput, D.Z.; Bulut, S.N. Chapter 8-Biopolymer Packaging Materials for Food Shelf-Life Prolongation. In Biopolymers for Food Design; Grumezescu, A.M., Holban, A.M., Eds.; AcademicPress: New York, NY, USA, 2018; pp. 223-277.

7. Majid, I.; Thakur, M.; Nanda, V. Biodegradable Packaging Materials. In Reference Module in Materials Science and Materials Engineering; Elsevier: Amsterdam, The Netherlands, 2018.

8. Robertson, G. 1-State-of-the-art biobased food packaging materials. In Environmentally Compatible Food Packaging; Chiellini, E., Ed.; Woodhead Publishing: Sawston, UK, 2008; pp. 3-28. 
9. Cazón, P.; Velazquez, G.; Ramírez, J.A.; Vázquez, M. Polysaccharide-based films and coatings for food packaging: A review. Food Hydrocoll. 2017, 68, 136-148. [CrossRef]

10. Mikkonen, K.S.; Rita, H.; Helén, H.; Talja, R.A.; Hyvönen, L.; Tenkanen, M. Effect of Polysaccharide Structure on Mechanical and Thermal Properties of Galactomannan-Based Films. Biomacromolecules 2007, 8, 3198-3205. [CrossRef]

11. Hassan, B.; Chatha, S.A.S.; Hussain, A.I.; Zia, K.M.; Akhtar, N. Recent advances on polysaccharides, lipids and protein based edible films and coatings: A review. Int. J. Biol. Macromol. 2018, 109, 1095-1107. [CrossRef]

12. Kaewprachu, P.; Osako, K.; Benjakul, S.; Tongdeesoontorn, W.; Rawdkuen, S. Biodegradable Protein-based Films and Their Properties: A Comparative Study. Packag. Technol. Sci. 2016, 29, 77-90. [CrossRef]

13. Bourtoom, T. Edible protein films: Properties enhancement. Int. Food Res. J. 2011, 16, 1-9.

14. Schmid, M.; Müller, K. Chapter 11-Whey Protein-Based Packaging Films and Coatings. In Whey Proteins; Deeth, H.C., Bansal, N., Eds.; Academic Press: New York, NY, USA, 2019; pp. 407-437.

15. Caleb, O.J.; Ahajan, P.V.; Al-Said, F.A.; Opara, U.L. Transpirationrate and quality of omegranate arils as affected by storage conditions. Cyta J. Food 2013, 11, 199-207. [CrossRef]

16. González, A.; AlvarezIgarzabal, C.I. Nanocrystal-reinforced soy protein films and their application as active packaging. Food Hydrocoll. 2015, 43, 777-784. [CrossRef]

17. Krishna, M.; Nindo, C.I.; Min, S.C. Development of fish gelatin edible films using extrusion and compression molding. J. Food Eng. 2012, 108, 337-344. [CrossRef]

18. Pérez, L.M.; Piccirilli, G.N.; Delorenzi, N.J.; Verdini, R.A. Effect of different combinations of glycerol and/or trehaloseon physical and structural properties of whey protein concentrate-based edible films. Food Hydrocoll. 2016, 56, 352-359. [CrossRef]

19. Cao, N.; Fu, Y.; He, J. Preparation and physical properties of soy protein isolate and gelatin composite films. Food Hydrocoll. 2007, 21, 1153-1162. [CrossRef]

20. Maryam Adilah, Z.A.; Jamilah, B.; NurHanani, Z.A. Functional and antioxidant properties of protein-based films incorporated with mango kernel extract for active packaging. Food Hydrocoll. 2018, 74, 207-218. [CrossRef]

21. Murrieta-Martínez, C.L.; Soto-Valdez, H.; Pacheco-Aguilar, R.; Torres-Arreola, W.; Rodríguez-Felix, F.; MárquezRíos, E. Edible protein films: Sources and behavior. Packag. Technol. Sci. 2018, 31, 113-122. [CrossRef]

22. Zavareze, E.; ElHalal, S.; Silva, R.; Dias, A.; Prentice-Hernandez, C. Mechanical, barrier and morphological properties of biodegradable films based on muscle and waste proteins from the white mouth croaker. J. Food Process. Preserv. 2014, 38, 1973-1981. [CrossRef]

23. Letendre, M.; D'Aprano, G.; Lacroix, M.; Salmieri, S.; St-Gelais, D. Physicochemical properties and bacterial resistance of biodegradable milk protein films containing agar and pectin. J. Agric. Food Chem. 2002, 50, 6017-6022. [CrossRef]

24. Guerrero, P.; Caba, K.D.L. Protein-Based Films and Coatings. Contemp. Food Eng. 2016, 81-120.

25. Vieira, M.G.A.; DaSilva, M.A.; DosSantos, L.O.; Beppu, M.M. Natural-based plasticizers and biopolymer films: A review. Eur. Polym. J. 2011, 47, 254-263. [CrossRef]

26. Brault, D.; Daprano, G.; Lacroix, M. Formation of free-standing sterilized edible films from irradiated caseinates. J. Agric. Food Chem. 1997, 45, 2964-2969. [CrossRef]

27. Jenkins, A.D. Fundamental Principles of Polymeric Materials. Biomaterials 1982, 3, 253. [CrossRef]

28. Swain, S.N.; Biswal, S.M.; Nanda, P.K.; Nayak, P.L. Biodegradable Soy-Based Plastics: Opportunities and Challenges. J. Polym. Environ. 2004, 12, 35-42. [CrossRef]

29. Ananey-Obiri, D.; Matthews, L.; Azahrani, M.H.; Ibrahim, S.A.; Galanakis, C.M.; Tahergorabi, R. Application of protein-based edible coatings for fat uptake reduction in deep-fatfried foods with an emphasis on muscle food proteins. Trends Food Sci. Technol. 2018, 80, 167-174. [CrossRef]

30. Cuq, B.; Gontard, N.; Cuq, J.-L.; Guilbert, S. Selected Functional Properties of Fish Myofibrillar Protein-Based Films As Affected by Hydrophilic Plasticizers. J. Agric. Food Chem. 1997, 45, 622-626. [CrossRef]

31. Ou, S.; Wang, Y.; Tang, S.; Huang, C.; Jackson, M.G. Role of ferulicacid in preparing edible films from soy protein isolate. J. Food Eng. 2005, 205-210. [CrossRef]

32. Karbowiak, T.; Hervet, H.; Léger, L.; Champion, D.; Debeaufort, F.; Voilley, A. Effect of Plasticizers (Water and Glycerol) on the Diffusion of a Small Moleculein Iota-Carrageenan Biopolymer Films for Edible Coating Application. Biomacromolecules 2006, 7, 2011-2019. [CrossRef] [PubMed] 
33. Zhang, Y.; Han, J.H. Mechanical and thermal characteristics of pea starch films plasticized with monosaccharides and polyols. J. Food Sci. 2006, E109-E118. [CrossRef]

34. Kristo, E.; Biliaderis, C.G. Water sorption and thermo-mechanical properties of water/sorbitol - plasticized composite biopolymer films: Caseinate-pullulan bilayers and blends. Food Hydrocoll. 2006, 20, 1057-1071. [CrossRef]

35. Cao, N.; Yang, X.; Fu, Y. Effects of various plasticizers on mechanical and water vapor barrier properties of gelatin films. Food Hydrocoll. 2009, 23, 729-735. [CrossRef]

36. Suyatma, N.E.; Tighzert, L.; Copinet, A.; Coma, V. Effects of hydrophilic plasticizers on mechanical, thermal, and surface properties of chitosan films. J. Agric. Food Chem. 2005, 53, 3950-3957. [CrossRef] [PubMed]

37. Audic, J.-L.; Chaufer, B. Influence of plasticizers and crosslinking on the properties of biodegradable films made from sodium caseinate. Eur. Polym. J. 2005, 41, 1934-1942. [CrossRef]

38. Jangchud, A.; Chinnan, M.S. Properties of Peanut Protein Film: Sorption Isotherm and Plasticizer Effect. Food Sci. Technol. 1999, 32, 89-94. [CrossRef]

39. Smits, A.L.M.; Kruiskamp, P.H.; VanSoest, J.J.G.; Vliegenthart, J.F.G. Interaction between dry starch and plasticizers glycerol or ethylene glycol, measured by differential scanning calorimetry and solid state NMR spectroscopy. Carbohydr. Polym. 2003, 53, 409-416. [CrossRef]

40. Honary, S.; Orafai, H. The Effect of Different Plasticizer Molecular Weights and Concentrations on Mechanical and Thermomechanical Properties of Free Films. Drug Dev. Ind. Pharm. 2002, 711-715. [CrossRef]

41. Talja, R.A.; Helén, H.; Roos, Y.H.; Jouppila, K. Effect of various polyols and polyolcontents on physical and mechanical properties of potato starch-based films. Carbohydr. Polym. 2007, 67, 288-295. [CrossRef]

42. Navarro-Tarazaga, M.L.; Sothornvit, R.; Perez-Gago, M.B. Effect of Plasticizer Type and Amount on Hydroxypropyl Methylcellulose-Beeswax Edible Film Properties and Postharvest Quality of Coated Plums (Cv. Angeleno). J. Agric. Food Chem. 2008, 56, 9502-9509. [CrossRef]

43. Galdeano, M.C.; Mali, S.; Grossmann, M.V.E.; Yamashita, F.; García, M.A. Effects of plasticizers on the properties of oat starch films. Mater. Sci. Eng. C 2009, 29, 532-538. [CrossRef]

44. Veiga-Santos, P.; Oliveira, L.M.; Cereda, M.P.; Scamparini, A.R.P. Sucrose and inverted sugar as plasticizer. Effect on cassavastarch-gelatin film mechanical properties, hydrophilicity and water activity. Food Chem. 2007, 103, 255-262. [CrossRef]

45. Pommet, M.; Redl, A.; Morel, M.-H.; Guilbert, S. Study of wheat gluten plasticization with fatty acids. Polymer 2003, 44, 115-122. [CrossRef]

46. Jongjareonrak, A.; Benjakul, S.; Visessanguan, W.; Tanaka, M. Fatty acids and their sucroseesters affect the properties of fish skin gelatin-based film. Eur. Food Res. Technol. 2006, 222, 650-657. [CrossRef]

47. Santosa, F.X.B.; Padua, G.W. Tensile Properties and Water Absorption of Zein Sheets Plasticized with Oleic and Linoleic Acids. J. Agric. Food Chem. 1999, 47, 2070-2074. [CrossRef] [PubMed]

48. Huang, M.; Yu, J.; Ma, X. Ethanolamine as a novel plasticiser for thermo plastic starch. Polym. Degrad. Stab. 2005, 90, 501-507. [CrossRef]

49. Galdeano, M.C.; Grossmann, M.V.E.; Mali, S.; Bello-Perez, L.A.; Garcia, M.A.; Zamudio-Flores, P.B. Effects of production process and plasticizers on stability of films and sheets of oat starch. Mater. Sci. Eng. C: Biomim. Mater. Sens. Syst. 2009, 29, 492-498. [CrossRef]

50. Stein, T.M.; Gordon, S.H.; Greene, R.V. Amino acids as plasticizers II. Use of quantitative structure-Property relationships to predict the behavior of monoammonium monocarboxylate plasticizers in starch-glycerol blends. Carbohydr. Polym. 1999, 39, 7-16. [CrossRef]

51. Kim, S.-J.; Ustunol, Z. Solubility and Moisture Sorption Isotherms of Whey-Protein-Based Edible Films as Influenced by Lipid and Plasticizer Incorporation. J. Agric. Food Chem. 2001, 49, 4388-4391. [CrossRef]

52. Sobral, P.J.D.A.; Santos, J.S.D.; García, F.T. Effect of protein and plasticizer concentrations in film forming solutions on physical properties of edible films based on muscle proteins of a Thai Tilapia. J. Food Eng. 2004, 70, 93-100. [CrossRef]

53. Galietta, G.; Gioia, L.D.; Guilbert, S.; Cuq, B. Mechanical and thermomechanical properties offilms based on whey proteins as affected by plasticizer and crosslinking agents. J. Dairy Sci. 1998, 81, 3123-3130. [CrossRef]

54. Bergo, P.; Sobral, P.J.A. Effects of plasticizer on physical properties of pig skin gelatin films. Food Hydrocoll. 2007, 21, 1285-1289. [CrossRef]

55. Sobral, P.J.A.; Menegalli, F.C.; Hubinger, M.D.; Roques, M.A. Mechanical, water vapor barrier and thermal properties of gelatin based edible films. Food Hydrocoll. 2001, 15, 423-432. [CrossRef] 
56. Bertan, L.C.; Tanada-Palmu, P.S.; Siani, A.C.; Grosso, C.R.F. Effect of fatty acids and 'Brazilianelemi' on composite films based on gelatin. Food Hydrocoll. 2005, 19, 73-82. [CrossRef]

57. Carvalho, R.A.; Ferreira Grosso, C.R.; Sobral, P.J.A. Effect of chemical treatment on the mechanical properties, water vapour permeability and sorption isotherms of gelatin-based films. Packag. Technol. Sci. 2008, 21, 165-169. [CrossRef]

58. Jiménez-Rosado, M.; Zarate-Ramírez, L.S.; Romero, A.; Bengoechea, C.; Partal, P.; Guerrero, A. Bioplastics based on wheat gluten processed by extrusion. J. Clean. Prod. 2019, 239, 117994. [CrossRef]

59. Gao, C.; Stading, M.; Wellner, N.; Parker, M.; Noel, T.; Mills, E.; Belton, P. Plasticization of a protein-based film by glycerol: A spectroscopic, mechanical, and thermal study. J. Agric. Food Chem. 2006, 54, 4611-4616. [CrossRef] [PubMed]

60. Fox, P.F.; Brodkorb, A. The casein micelle: Historical aspects, current concepts and significance. Int. Dairy J. 2008, 18, 677-684. [CrossRef]

61. Ramos, Ó.L.; Reinas, I.; Silva, S.I.; Fernandes, J.C.; Cerqueira, M.A.; Pereira, R.N.; Vicente, A.A.; Poças, M.F.; Pintado, M.E.; Malcata, F.X. Effect of whey protein purity and glycerol content upon physical properties of edible films manufactured therefrom. Food Hydrocoll. 2013, 30, 110-122. [CrossRef]

62. Wieser, H. Chemistry of gluten proteins. Food Microbiol. 2007, 24, 115-119. [CrossRef] [PubMed]

63. Cuq, B.; Gontard, N.; Guilbert, S. Proteins as agricultural polymers for packaging production. Cereal Chem. 1998, 75, 1-9. [CrossRef]

64. Mangavel, C.; Rossignol, N.; Perronnet, A.; Barbot, J.; Popineau, Y.; Guéguen, J. Properties and microstructure of thermo-pressed wheat gluten films: A comparison with cast films. Biomacromolecules 2004, 5, 1596-1601. [CrossRef]

65. Gällstedt, M.; Mattozzi, A.; Johansson, E.; Hedenqvist, M.S. Transport and tensile properties of compression-molded wheat gluten films. Biomacromolecules 2004, 5, 2020-2028. [CrossRef]

66. Zuo, M.; Song, Y.; Zheng, Q. Preparation and properties of wheat gluten/methylcellulose binary blend film casting from aqueous ammonia: A comparison with compression molded composites. J. Food Eng. 2009, 91, 415-422. [CrossRef]

67. Gennadios, A.; Brandenburg, A.H.; Weller, C.L.; Testin, R.F. Effect of $\mathrm{pH}$ on properties of wheat gluten and soy protein isolate films. J. Agric. Food Chem. 1993, 41, 1835-1839. [CrossRef]

68. Arnon-Rips, H.; Poverenov, E. Improving food products' quality and storability by using Layer by Layer edible coatings. Trends Food Sci. Technol. 2018, 75, 81-92. [CrossRef]

69. Krochta, J.; Mulder-Johnston, C. Edible and Biodegradable Polymer Films: Challenges and Opportunities. Food Technol. 1997, 51, 61-74.

70. Gennadios, A.; Weller, C.; Testin, R. Modification of physical and barrier properties of edible wheat gluten-based films. Cereal Chem. 1993, 70, 426-429.

71. Ansorena, M.R.; Zubeldía, F.; Marcovich, N.E. Active wheat gluten films obtained by thermo plastic processing. Lwt Food Sci. Technol. 2016, 69, 47-54. [CrossRef]

72. Baldwin, E.; Hagenmaier, R.; Bai, J. Edible Coatings and Films to Improve Food Quality; CRC Press: Boca Raton, FL, USA, 1994; Volume 33, pp. 86-87.

73. Tian, H.; Guo, G.; Fu, X.; Yao, Y.; Yuan, L.; Xiang, A. Fabrication, properties and applications of soy-protein-based materials: A review. Int. J. Biol. Macromol. 2018, 120, 475-490. [CrossRef]

74. Mariniello, L.; DiPierro, P.; Esposito, C.; Sorrentino, A.; Masi, P.; Porta, R. Preparation and mechanical properties of edible pectin-soy flour films obtained in the absence or presence of transglutaminase. J. Biotechnol. 2003, 102, 191-198. [CrossRef]

75. SeungYong, C.; Chul, R. Mechanical properties and water vapor permeability of edible films made from fractionated soy proteins with ultra filtration. Lebensm. Wiss. Und-Technol. 2004, 37, 833-839.

76. Wu, L.C.; Bates, R.P. Soy protein-lipid films. 1. Studies on the Film Formation Phenomenon. J. Food Sci. 1972, 31, 36-39.

77. Ghorpade, V.M.; Hanna, M.A. Mechanical Properties of Soy Protein-polyethylene Ribbon and Film Extrudates. Trans. Asabe 1996, 39, 611-615. [CrossRef]

78. Rampon, V.; Robert, P.; Nicolas, N.; Dufour, E. Protein structure and network orientationin edible films prepared by spinning process. J. Food Sci. 1999, 64, 313-316. [CrossRef]

79. Ogale, A.A.; Cunningham, P.; Dawson, P.L.; Acton, J.C. Viscoelastic, thermal, and microstructural characterization of soy protein isolate films. J. Food Sci. 2000, 65, 672-679. [CrossRef] 
80. Rayner, M.; Ciolfi, V.; Maves, B.; Stedman, P.; Mittal, G.S. Development and application of soy-protein films to reduce fat intake in deep-fried foods. J. Sci. Food Agric. 2000, 80, 777. [CrossRef]

81. Dehghani, S.; Hosseini, S.V.; Regenstein, J.M. Edible films and coatings in seafood preservation: A review. Food Chem. 2018, 240, 505-513. [CrossRef] [PubMed]

82. Rhi, M. Sodium dodecyl sulfate treatment improves properties of cast films soy protein isolate. Ind. Crop. Prod. 2002, 15, 199-205.

83. Sabato, S.; Ouattara, B.; Yu, H.; D’Aprano, G.; Tien, C.L.; Mateescu, M.; Lacroix, M. Mechanical and barrier properties of cross-linked soy and whey protein based films. J. Agric. Food Chem. 2001, 49, 1397-1403. [CrossRef]

84. Soares, R.M.D.; Scremin, F.F.; Soldi, V. Thermal Stability of Biodegradable Films Based on Soy Protein and Corn Starch. Macromol. Symp. 2005, 229, 258-265. [CrossRef]

85. Rhim, J.; Handa, A.; Weller, C.; Hanna, M.; Gennadios, A. Solubility, tensile, and color properties of modified soy protein isolate films. J. Agric. Food Chem. 2000, 48, 4937-4941. [CrossRef]

86. Shukla, R.; Cheryan, M. Zein: The industrial protein from corn. Ind. Crop. Prod. 2001, 13, 171-192. [CrossRef]

87. Beck, M.I.; Tomka, I.; Waysek, E. Physico-chemical characterization of zein as a film coating polymer A direct comparison with ethylcellulose. Int. J. Pharm. 1996, 141, 137-150. [CrossRef]

88. Soliman, E.; Eldin, M.M.; Furuta, M. Biodegradable zein-based films: Influence of gamma-irradiation on structural and functional properties. J. Agric. Food Chem. 2009, 57, 2529-2535. [CrossRef] [PubMed]

89. Dickey, L.C.; Parris, N.; Craig, J.C.; Kurantz, M.J. Ethanolic extraction of zein from maize. Ind. Crop. Prod. 2001, 13, 67-76. [CrossRef]

90. Dickey, L.C.; Parris, N.; Craig, J.C.; Kurantz, M.J. Serial batch extraction of zein from milled maize. Ind. Crop. Prod. 2002, 15, 33-42. [CrossRef]

91. Landry, J. Comparison of Extraction Methods for Evaluating Zein Conten tof Maize Grain. Cereal Chem. 1997, 74, 188-189. [CrossRef]

92. Wang, Q.; Geil, P.; Padua, G. Role of Hydrophilic and Hydrophobic Interactionsin Structure Development of Zein Films. J. Polym. Environ. 2004, 12, 197-202. [CrossRef]

93. Kim, S.; Sessa, D.J.; Lawton, J.W. Characterization of zein modified with a mild cross-linking agent. Ind. Crop. Prod. 2004, 20, 291-300. [CrossRef]

94. Wang, Y.; Padua, G.W. Water Sorption Properties of Extruded Zein Films. J. Agric. Food Chem. 2004, 52, 3100-3105. [CrossRef]

95. Kleen, D.; Padua, G.; Engeseth, N. Stabilization of lipids in a biodegradable zein-oleate film by incorporation of antioxidants. Cereal Chem. 2002, 79, 687-694. [CrossRef]

96. Wang, Y.; Rakotonirainy, A.; Padua, G. Thermal behavior of zein-based biodegradable films. Starch-Starke 2003, 55, 25-29. [CrossRef]

97. Khwaldia, K.; Perez, C.; Banon, S.; Desobry, S.; Hardy, J. Milk protein for edible films and coating. Crit. Rev. Food Sci. Nutr. 2004, 44, 239-251. [CrossRef]

98. Parris, N.; Coffin, D.R. Composition Factors Affecting the Water Vapor Permeability and Tensile Properties of Hydrophilic Zein Films. J. Agric. Food Chem. 1997, 45, 1596-1599. [CrossRef]

99. Wang, Q.; Padua, G.W. Properties of Zein Films Coated with Drying Oils. J. Agric. Food Chem. 2005, 53, 3444-3448. [CrossRef] [PubMed]

100. Audic, J.; Chaufer, B.; Daufin, G. Non-food applications of milk components and dairy co-products: A review. Le Lait 2003, 83, 417-438. [CrossRef]

101. Chiralt, A.; González-Martínez, C.; Vargas, M.; Atarés, L. 18-Edible films and coatings from proteins. In Proteins in Food Processing, 2nd ed.; Yada, R.Y., Ed.; Woodhead Publishing: Cambridge, UK, 2018; pp. 477-500.

102. MendesdeSouza, P.; Fernández, A.; López-Carballo, G.; Gavara, R.; Hernández-Muñoz, P. Modified sodium caseinate films as releasing carriers of lysozyme. Food Hydrocoll. 2010, 24, 300-306. [CrossRef]

103. Livney, Y.D. Milk proteins as vehicles for bioactives. Curr. Opin. Colloid Interface Sci. 2010, 15, 73-83. [CrossRef]

104. Belyamani, I.; Prochazka, F.; Assezat, G. Production and characterization of sodium caseinate edible films made by blown-film extrusion. J. Food Eng. 2014, 121, 39-47. [CrossRef]

105. Bonnaillie, M.L.; Zhang, H.; Akkurt, S.; Yam, L.K.; Tomasula, M.P. Casein Films: The Effects of Formulation, Environmental Conditions and the Addition of Citric Pectin on the Structure and Mechanical Properties. Polymers 2014, 6, 2018-2036. [CrossRef] 
106. Chevalier, E.; Assezat, G.; Prochazka, F.; Oulahal, N. Development and characterization of a novel edible extruded sheet based on different casein sources and influence of the glycerol oncentration. Food Hydrocoll. 2018, 75, 182-191. [CrossRef]

107. Sohail, S.S.; Wang, B.; Biswas, M.A.S.; Oh, J.-H. Physical, Morphological, and Barrier Properties of Edible Casein Films with Wax Applications. J. Food Sci. 2006, 71, C255-C259. [CrossRef]

108. Diak, O.A.; Bani-Jaber, A.; Amro, B.; Jones, D.; Andrews, G.P. The Manufacture and Characterization of Casein Films as Novel Tablet Coatings. Food Bioprod. Process. 2007, 85, 284-290. [CrossRef]

109. Farhan, A.; Hani, N.M. Characterization of edible packaging films based on semi-refined kappa-carrageenan plasticized with glycerol and sorbitol. Food Hydrocoll. 2017, 64, 48-58. [CrossRef]

110. Cao, N.; Fu, Y.; He, J. Mechanical properties of gelatin films cross-linked, respectively, by ferulic acid and tannin acid. Food Hydrocoll. 2007, 21, 575-584. [CrossRef]

111. Ghosh, A.; Ali, M.A.; Dias, G.J. Effect of cross-linking on microstructure and physical performance of casein protein. Biomacromolecules 2009, 10, 1681-1688. [CrossRef] [PubMed]

112. KeesdeKruif, C.G.; Anema, S.G.; Zhu, C.; Havea, P.; Coker, C. Water holding capacity and swelling of casein hydrogels. Food Hydrocoll. 2015, 44, 372-379.

113. Song, F.; Zhang, L.; Shi, J.; Li, N. Novel casein hydrogels: Formation, structure and controlled drug release. Colloids Surf. B-Biointerfaces 2010, 79, 142-148. [CrossRef]

114. Zhang, L.; Liang, R.; Chen, F.; He, L.; Hu, B.; Zeng, X. Cross-Linking of Interfacial Casein Layer with Genipin Prevented pH-Induced Structural Instability and Lipase Digestibility of the Fat Droplets. J. Agric. Food Chem. 2015, 63, 2033-2040.

115. Silva, N.N.; Saint-Jalmes, A.; Carvalho, A.F.D.; Gaucheron, F. Development of Casein Microgels from Cross-Linking of Casein Micelles by Genipin. Langmuir 2014, 30, 10167-10175. [CrossRef]

116. Song, F.; Zhang, L.; Yang, C.; Yan, L. Genipin-crosslinked casein hydrogels for controlled drug delivery. Int. J. Pharm. 2009, 373, 41-47. [CrossRef]

117. Picchio, M.L.; Linck, Y.G.; Monti, G.A.; Gugliotta, L.M.; Minari, R.J.; AlvarezIgarzabal, C.I. Casein films crosslinked by tannic acid for food packaging applications. Food Hydrocoll. 2018, 84, 424-434. [CrossRef]

118. Fabra, M.J.; Talens, P.; Chiralt, A. Effect of alginate and $\lambda$-carrageenan on tensile properties and water vapour permeability of sodium caseinate-lipid based films. Carbohydr. Polym. 2008, 74, 419-426. [CrossRef]

119. Pereda, M.; Aranguren, M.I.; Marcovich, N.E. Characterization of chitosan/caseinate films. J. Appl. Polym. Sci. 2008, 107, 1080-1090. [CrossRef]

120. Chick, J.; Hernandez, R.J. Physical, Thermal, and Barrier Characterization of Casein-Wax-Based Edible Films. J. Food Sci. 2002, 67, 1073-1079. [CrossRef]

121. Fabra, M.J.; Talens, P.; Chiralt, A. Microstructure and optical properties of sodium caseinate films containing oleicacid-beeswax mixtures. Food Hydrocoll. 2009, 23, 676-683. [CrossRef]

122. Avena-Bustillos, R.J.; Krochta, J.M. Water Vapor Permeability of Caseinate-Based Edible Films as Affected by pH, Calcium Crosslinking and Lipid Content. J. Food Sci. 1993, 58, 904-907. [CrossRef]

123. Baroli, B. Photopolymerization of biomaterials: Issues and potentialities in drug delivery, tissue engineering, and cellencapsulation applications. J. Chem. Technol. Biotechnol. 2006, 81, 491-499. [CrossRef]

124. Wihodo, M.; Moraru, C.I. Effect of Pulsed Light treatment on the functional properties of casein films. Lwt Food Sci. Technol. 2015, 64, 837-844. [CrossRef]

125. Jauregi, P.; Welderufael, F.T. Added-value protein products from whey: Extraction, fractionation, separation, purification. Nutrafoods 2010, 9, 13-23. [CrossRef]

126. Shimada, K.; Claude Cheftel, J. Sulfhydryl group/disulfide bond interchange reactions during heat-induced gelation of whey protein isolate. J. Agric. Food Chem. 2002, 37, 161-168. [CrossRef]

127. McHugh, T.H.; Krochta, J.M. Water vapor permeability properties of edible whey protein-lipid emulsion films. J. Am. Oil Chem. Soc. 1994, 71, 307-312. [CrossRef]

128. Mchugh, T.; Aujard, J.; Krochta, J. Plasticized whey protein edible films: Water vapor permeability properties. J. Food Sci. 1994, 59, 416-419. [CrossRef]

129. Lent, L.E.; Vanasupa, L.S.; Tong, P.S. Whey protein edible films tructures determined by atomic force microscope. J. Food Sci. 1998, 63, 824-827. [CrossRef]

130. Pérez-Gago, M.B.; Krochta, J.M. Water vapor permeability of whey protein emulsion films as affected by $\mathrm{pH}$. J. Food Sci. 1999, 64, 695-698. [CrossRef] 
131. Banerjee, R.; Chen, H. Functional properties of edible films using whey protein concentrate. J. Dairy Sci. 1995, 78, 1673-1683. [CrossRef]

132. Díaz, O.; Candia, D.; Cobos, Á. Effects of ultraviolet radiation on properties of films from whey protein concentratetreated before or after film formation. Food Hydrocoll. 2016, 55, 189-199. [CrossRef]

133. Bourtoom, T.; Chinnan, M.S.; Jantawat, P.; Sanguandeekul, R. Effect of select parameters on the properties of edible film from water-soluble fish proteins insurimi wash-water. Lwt Food Sci. Technol. 2006, 39, 406-419. [CrossRef]

134. Quinn, G.; Monahan, F.J.; O’Riordan, E.D.; O'Sullivan, M.; Longares, A. Role of Covalent and Noncovalent Interactions in the Formation of Films from Unheated Whey Protein Solutions Following pH Adjustment. J. Food Sci. 2003, 68, 2284-2288. [CrossRef]

135. Díaz, O.; Candia, D.; Cobos, Á. Whey protein film properties as affected by ultraviolet treatment under alkaline conditions. Int. Dairy J. 2017, 73, 84-91. [CrossRef]

136. Banerjee, R.; Chen, $\mathrm{H} . ; \mathrm{Wu}, \mathrm{J}$. Milk protein-based edible film mechanical strength changes due to ultrasound process. J. Food Sci. 1996, 61, 824-828. [CrossRef]

137. Javanmard, M.; Golestan, L. Effect of oliveoil and glycerol on physical properties of whey protein concentrate films. J. Food Process Eng. 2008, 31, 628-639. [CrossRef]

138. Shaw, N.B.; Monahan, F.J.; O’Riordan, E.D.; O'Sullivan, M. Effect of soya oil and glycerol on physical properties of composite WPI films. J. Food Eng. 2002, 51, 299-304. [CrossRef]

139. Kokoszka, S.; Debeaufort, F.; Lenart, A.; Voilley, A. Liquid and vapour water transfer through whey protein/lipide mulsion films. J. Sci. Food Agric. 2010, 90, 1673-1680. [CrossRef] [PubMed]

140. Soazo, M.; Pérez, L.M.; Rubiolo, A.C.; Verdini, R.A. Effect of freezing on physical properties of whey protein emulsion films. Food Hydrocoll. 2013, 31, 256-263. [CrossRef]

141. Pérez-Gago, M.B.; Krochta, J.M. Lipid Particle Size Effect on Water Vapor Permeability and Mechanical Properties of Whey Protein/Beeswax Emulsion Films. J. Agric. Food Chem. 2001, 49, 996-1002. [CrossRef] [PubMed]

142. Janjarasskul, T.; Rauch, D.J.; McCarthy, K.L.; Krochta, J.M. Barrier and tensile properties of whey protein-candelilla wax film/sheet. Lwt Food Sci. Technol. 2014, 56, 377-382. [CrossRef]

143. Fernández, L.; DeApodaca, E.D.; Cebrián, M.; Villarán, M.C.; Maté, J.I. Effect of the unsaturation degreeand concentration offatty acids on the properties of WPI-based edible films. Eur. Food Res. Technol. 2007, 224, 415-420. [CrossRef]

144. Anker, M.; Berntsen, J.; Hermansson, A.-M.; Stading, M. Improved water vapor barrier of whey protein films by addition of an acetylated monoglyceride. Innov. Food Sci. Emerg. Technol. 2002, 3, 81-92. [CrossRef]

145. Ta, K. Handbook of Engineering Biopolymers; Homopolymers, Blends, and Composites; Sci-Tech News Carl Hanser Verlag GmbH \& CO. KG: Munich, Germany, 2007; Volume 61, p. 64.

146. Jongjareonrak, A.; Benjakul, S.; Visessanguan, W.; Prodpran, T.; Tanaka, M. Characterization of edible films from skin gelatin of brown stripered snapper and big eye snapper. Food Hydrocoll. 2006, 20, 492-501. [CrossRef]

147. Menegalli, F.C.; Sobral, P.J.; Roques, M.A.; Laurent, S. Characteristics of gelatin biofilms in relation to drying process conditions near melting. Dry. Technol. 1999, 17, 1697-1706. [CrossRef]

148. Fraga, A.N.; Williams, R.J.J. Thermal properties of gelatin films. Polymer 1985, 26, 113-118. [CrossRef]

149. Andreuccetti, C.; Carvalho, R.A.; Galicia-García, T.; Martinez-Bustos, F.; González-Nuñez, R.; Grosso, C.R.F. Functional properties of gelatin-based films containing Yuccaschidigera extract produced via casting, extrusion and blown extrusion processes: Apreliminary study. J. Food Eng. 2012, 113, 33-40. [CrossRef]

150. Tongnuanchan, P.; Benjakul, S.; Prodpran, T. Properties and antioxidant activity of fish skin gelatin film incorporated with citrus essential oils. Food Chem. 2012, 134, 1571-1579. [CrossRef] [PubMed]

151. Ahmad, M.; Benjakul, S.; Prodpran, T.; Agustini, T.W. Physico-mechanical and antimicrobial properties of gelatin film from the skin of unicorn leather jacket incorporated with essential oils. Food Hydrocoll. 2012, 28, 189-199. [CrossRef]

152. Kavoosi, G.; Dadfar, S.M.M.; Purfard, A.M. Mechanical, physical, antioxidant, and antimicrobial properties of gelatin films incorporated with thymol for potential use as nano wound dressing. J. Food Sci. 2013, 78, E244-E250. [CrossRef] [PubMed] 
153. Oms-Oliu, G.; Soliva-Fortuny, R.; Martín-Belloso, O. Edible coatings with antibrowning agents to maintain sensory quality and antioxidant properties of fresh-cut pears. Postharvest Biol. Technol. 2008, 50, 87-94. [CrossRef]

154. Galus, S.; Kadzińska, J. Food applications of emulsion-based edible films and coatings. Trends Food Sci. Technol. 2015, 45, 273-283. [CrossRef]

155. O'Sullivan, M.G. Chapter6-Shelf Life and Sensory Quality of Foods and Beverages. In A Handbookfor Sensory and Consumer-Driven New Product Development; O'Sullivan, M.G., Ed.; Woodhead Publishing: Cambridge, UK, 2017; pp. 103-123.

156. Westall, S.; Filtenborg, O. Spoilage yeasts of decorated soft cheese packed in modified atmosphere. Food Microbiol. 1998, 15, 243-249. [CrossRef]

157. DeGruson, M.L. Biobased Packaging. In Reference Module in Food Science; Elsevier: Amsterdam, The Netherlands, 2016.

158. Han, J.-W.; Kim, B.; Li, J.; Meyyappan, M. Carbon Nanotube Based Humidity Sensoron Cellulose Paper. J. Phys. Chem. C 2012, 116, 22094-22097. [CrossRef]

159. Shayanfar, S. Modified atmosphere packaging for fresh produce. Glob. Saf. Fresh Prod. 2014, 42, 175-186.

160. Robertson, G.L. Food Packaging: Principles and Practice; Taylor\&Francis/CRCPress: NewYork, NY, USA, 1993.

161. Floros, J. Controlled and Modified Atmospheres in Food Packaging and Storage. Chem. Eng. Prog. 1990, 86, 25-32.

162. Park, H.J.; Chinnan, M.S.; Shewfelt, R.L. Edible Coating Effects on Storage Life and Quality of Tomatoes. J. Food Sci. 1994, 59, 568-570. [CrossRef]

163. Park, H.J.; Rhim, J.W.; Lee, H.Y. Edible Coating Effects on Respiration Rate and Storage Life of "Fuji" Apples and "Shingo" Pears. Food Sci. Biotechnol. 1996, 5, 59-63.

164. Paul, S.K. Edible Films and Coatings for Fruits and Vegetables. In Reference Module in Materials Science and Materials Engineering; Elsevier: Amsterdam, The Netherlands, 2019.

165. Wang, X.; Kong, D.; Ma, Z.; Zhao, R. Effect of carrot puree edible films on quality preservation of fresh-cut carrots. Ir. J. Agric. Food Res. 2015, 54, 64-71. [CrossRef]

166. Licodiedoff, S.; Koslowski, L.; Scartazzini, L.; Monteiro, A.; Ninow, J.; Borges, C. Conservation of physalis by ediblecoating of gelatin and calciumchloride. Int. Food Res. J. 2016, 23, 1629-1634.

167. Zhang, B.; Feng, X.; Han, P.; Duan, X. Effect of propolis/nano-silica composite coating on activities of ripening and senescence related enzymesin cherry tomato fruits. J. Chin. Inst. Food Sci. Technol. 2016, 16, 159-165.

168. Poverenov, E.; Zaitsev, Y.; Arnon, H.; Granit, R.; Alkalai-Tuvia, S.; Perzelan, Y.; Weinberg, T.; Fallik, E. Effects of a composite chitosan-gelatin edible coating on postharvest quality and storability of red bellpeppers. Postharvest Biol. Technol. 2014, 96, 106-109. [CrossRef]

169. Andrade, R.; Skurtys, O.; Osorio, F. Drop impact of gelatin coating formulated with cellulose nanofibers on banana and eggplant epicarps. LwtFood Sci. Technol. 2015, 61, 422-429. [CrossRef]

170. Poverenov, E.; Rutenberg, R.; Danino, S.; Horev, B.; Rodov, V. Gelatin-Chitosan Composite Films and Edible Coatings to Enhance the Quality of Food Products: Layer-by-Layervs. Blended Formulations. Food Bioprocess Technol. 2014, 7, 3319-3327. [CrossRef]

171. Fakhouri, F.M.; Casari, A.C.A.; Mariano, M.; Yamashita, F.; Mei, L.H.I.; Soldi, V.; Martelli, S.M. Effect of a gelatin-based edible coating containing cellulos enanocrystals $(\mathrm{CNC})$ on the quality and nutrient retention of fresh strawberries during storage. In Proceedings of the 2nd International Conference on Structural Nano Composites (Nanostruc 2014), IOP Conference Series: Materials Science and Engineering, Madrid, Spain, 20-21 May 2014.

172. Bizura Hasida, M.R.; NurAida, M.P.; Zaipun, M.Z.; Hairiyah, M. Quality evaluation of fresh-cut 'josapine' pineapple coated with hydrocolloid based edible coating using gelatin. Vii Int. Postharvest Symp. 2013, 1012, 1037-1041. [CrossRef]

173. Feng, D.; Zhengguang, W.; Yimei, Z.; Xiang, Z.; Meng, G.; Xu, Y.; Bi, Y. Effect of chitosan composite coating on Chinese blueberry fruit (Vaccinium uliginosum L.). Ii Int. Symp. Discov. Dev. Innov. Strateg. Postharvest Dis. Manag. 2014, 1053, 207-211.

174. NevesJunior, A.C.V.; Coneglian, R.C.C.; Soares, A.G.; Freitas, D.G.C.; Fonseca, M.J.O.; Barreira, F.R.; Miranda, A.F.M.D.; BECantwell, M.I.; Almeida, D.P.F. Physical and sensory characterization of edible coatings applied to minimally processed persimmon. Acta Hortic. 2012, 934, 537-542. [CrossRef] 
175. Fox, P.F.; McSweeney, P.L.H. Chapter1-Cheese: An Overview. In Cheese, 4th ed.; Springer US: New York, NY, USA, 2017; pp. 5-21.

176. Pantaleão, I.; Pintado, M.M.E.; Poças, M.F.F. Evaluation of two packaging systems for regional cheese. Food Chem. 2007, 102, 481-487. [CrossRef]

177. Cerqueira, M.A.; Sousa-Gallagher, M.J.; Macedo, I.; Rodriguez-Aguilera, R.; Souza, B.W.S.; Teixeira, J.A.; Vicente, A.A. Use of galactomannan edible coating application and storage temperature for prolonging shelf-life of "Regional" cheese. J. Food Eng. 2010, 97, 87-94. [CrossRef]

178. Unalan, I.U.; Arcan, I.; Korel, F.; Yemenicioglu, A. Application of active zein-based films with controlled release properties to control Listeria monocytogenes growth and lipid oxidation in fresh Kashar cheese. Innov. Food Sci. Emerg. Technol. 2013, 20, 208-214. [CrossRef]

179. DiPierro, P.; Sorrentino, A.; Mariniello, L. Chitosan/whey protein film as active coating to extend Ricotta cheese shelf-life. LwtFood Sci. Technol. 2011, 44, 2324-2327.

180. Wagh, Y.R.; Pushpadass, H.A.; Emerald, F.M.E.; Nath, B.S. Preparation and characterization of milk protein films and their application for packaging of Cheddar cheese. J Food Sci Technol 2014, 51, 3767-3775. [CrossRef]

181. Cao-Hoang, L.; Chaine, A.; Grégoire, L.; Waché, Y. Potential of nisin-incorporated sodium caseinate films to control Listeriain artificially contaminated cheese. Food Microbiol. 2010, 27, 940-944. [CrossRef]

182. Moreira, M.D.R.; Pereda, M.; Marcovich, N.E.; Roura, S.I. Antimicrobial Effectiveness of Bioactive Packaging Materials from Edible Chitosan and Casein Polymers: Assessmenton Carrot, Cheese, and Salami. J. Food Sci. 2011, 76, M54-M63. [CrossRef]

183. Ture, H.; Eroglu, E.; Banu, O.; Soyer, F. Effect of biopolymers containing natamycin against Aspergillus niger and Penicillium roquefortii on fresh kashar cheese. Int. J. Food Sci. Technol. 2011, 46, 154-160. [CrossRef]

184. Bartkowski, L.; Dryden, F.D.; Marchello, J.A. Quality Changes of Beef Steaks Stored in Controlled Gas Atmospheres Containing High or Low Levels of Oxygen. J. Food Prot. 1982, 45, 41-45. [CrossRef]

185. Andersen, H.J.; Bertelsen, G.; Boegh-Soerensen, L.; Shek, C.K.; Skibsted, L.H. Effect of light and packaging conditions on the colour stability of sliced ham. Meat Sci. 1988, 22, 283-292. [CrossRef]

186. Andersen, H.J.; Bertelsen, G.; Ohlen, A.; Skibsted, L.H. Modified packaging as protection against photo degradation of the colour of pasteurized, sliced ham. Meat Sci. 1990, 28, 77-83. [CrossRef]

187. Andersen, H.J.; Skibsted, L.H. Kinetics and mechanism of thermal oxidation and photooxidation of nitrosylmyoglobin in aqueous solution. J. Agric. Food Chem. 1992, 40, 1741-1750. [CrossRef]

188. Holman, B.W.B.; Kerry, J.P.; Hopkins, D.L. Meat packaging solutions to current industry challenges: A review. Meat Sci. 2018, 144, 159-168. [CrossRef] [PubMed]

189. Khosrozadeh, A.; Darabi, M.A.; Xing, M.; Wang, Q. Flexible Electrode Design: Fabrication of Freestanding Polyaniline-Based Composite Films for High-Performance Supercapacitors. ACS Appl. Mater. Interfaces 2016, 8, 11379-11389. [CrossRef] [PubMed]

190. Badr, K.R.; Ahmed, Z.S.; ElGamal, M.S. Evaluation of the Antimicrobial Action of Whey Protein Edible Films Incorporated with Cinnamon, Cumin and Thyme Against Spoilage Flora of FreshBeef. Int. J. Agric. Res. 2014, 9, 242-250.

191. Alparslan, Y.; Baygar, T.; Baygar, T.; Yapıc1, H.; Metin, C. Effects of Gelatin-Based Edible Films Enriched with Laurel Essential Oil on the Quality of Rainbow Trout (Oncorhynchus mykiss) Fillets during Refrigerated Storage. Food Technol. Biotechnol. 2014, 52, 325-333.

192. Nagarajan, M.; Benjakul, S.; Prodpran, T.; Songtipya, P. Effects of bio-nanocomposite films from tilapia and squid skin gelatins incorporated with ethanolic extract from coconut husk on storage stability of mackerel meat powder. Food Packag. Shelf Life 2015, 6, 42-52. [CrossRef]

193. Emiroğlu, Z.K.; Yemiş, G.P.; Coşkun, B.K.; Candoğan, K. Antimicrobial activity of soy edible films incorporated with thyme and oregano essential oils on fresh ground beef patties. Meat Sci. 2010, 86, 283-288. [CrossRef]

194. Coşkun, B.K.; Çalikoğlu, E.; Emiroğlu, Z.K.; Candoğan, K. Antioxidant Active Packaging with Soy Edible Films and Oregano or Thyme Essential Oils for Oxidative Stability of Ground Beef Patties. J. Food Qual. 2014, 37, 203-212. [CrossRef]

195. Zinoviadou, K.G.; Koutsoumanis, K.P.; Biliaderis, C.G. Physical and thermo-mechanical properties of whey protein isolate films containing antimicrobials, and their effect against spoilage flora of fresh beef. Food Hydrocoll. 2010, 24, 49-59. [CrossRef] 
196. Thaker, M.; Hanjabam, M.D.; Gudipati, V.; Kannuchamy, N. Protective Effect of Fish Gelatin-Based Natural Antimicrobial Coatings on Quality of Indian Salmon Fillets during Refrigerated Storage. J. Food Process Eng. 2017, 40. [CrossRef]

197. Shokri, S.; Ehsani, A.; Jasour, M.S. Efficacy of Lactoperoxidase System - Whey Protein Coating on Shelf-life Extension of Rainbow Trout Fillets During Cold Storage $\left(4^{\circ} \mathrm{C}\right)$. Food Bioprocess Technol. 2015, 8, 54-62. [CrossRef]

198. Chen, B.; Zhou, Y.; Wei, X.; Xie, H.; Hider, R.; Zhou, T. Edible Antimicrobial Coating Incorporating a Polymeric Iron Chelator and Its Application in the Preservation of Surimi Product. Food Bioprocess Technol. 2016, 9, 1031-1039. [CrossRef]

199. Christophersen, A.G.; Bertelsen, G.; Andersen, H.; Knuthsen, P.; Skibsted, L. Storage life of frozen salmonoids Effect of light and packaging conditions on carotenoid oxidation and lipid oxidation. Z. Unters. Nahr. Genußmittelsowie Gebrauchsgegenstände 1992, 194, 115-119. [CrossRef]

200. Bak, L.S.; Andersen, A.B.; Andersen, E.M.; Bertelsen, G. Effect of modified atmosphere packaging on oxidative changes in frozen stored cold water shrimp (Pandalus borealis). Food Chem. 1999, 64, 169-175. [CrossRef]

201. Aguilera Barraza, F.A.; León, R.A.Q.; Álvarez, P.X.L. Kinetics of protein and textural changes in Atlantic salmon under frozen storage. Food Chem. 2015, 182, 120-127. [CrossRef]

202. Rodriguez-Turienzo, L.; Cobos, A.; Diaz, O. Effects of edible coatings based on ultrasound-treated whey proteins in quality attributes of frozen Atlantic salmon (Salmo salar). Innov. Food Sci. Emerg. Technol. 2012, 14, 92-98. [CrossRef]

203. Rodriguez-Turienzo, L.; Cobos, A.; Moreno, V.; Caride, A.; Vieites, J.M.; Diaz, O. Whey protein-based coatings on frozen Atlantic salmon (Salmo salar): Influence of the plasticiser and themoment of coating on quality preservation. Food Chem. 2011, 128, 187-194. [CrossRef]

204. Rodriguez-Turienzo, L.; Cobos, A.; Diaz, O. Effects of microbial transglutaminase added edible coatings based on heated or ultrasound-treated whey proteins in physical and chemical parameters of frozen Atlantic salmon (Salmo salar). J. Food Eng. 2013, 119, 433-438. [CrossRef]

205. Seyfzadeh, M.; Motalebi, A.A.; Kakoolaki, S.; Gholipour, H. Chemical, microbiological and sensory evaluation of guttedkilka coated with whey protein based edible film incorporated with sodium alginate during frozen storage. Iran. J. Fish. Sci. 2013, 12, 140-153.

206. Min, B.J.; Oh, J.-H. Antimicrobial Activity of Catfish Gelatin Coating Containing Origanum (Thymus capitatus) Oil against Gram-Negative Pathogenic Bacteria. J. Food Sci. 2009, 74, M143-M148. [CrossRef] [PubMed]

207. Sánchez-Ortega, I.; García-Almendárez, B.E.; Santos-López, E.M.; Amaro-Reyes, A.; Barboza-Corona, J.E.; Regalado, C. Antimicrobial Edible Films and Coatings for Meat and Meat Products Preservation. Sci. World J. 2014, 2014, 248935. [CrossRef] [PubMed]

208. Zhong, Y.; Godwin, P.; Jin, Y.; Xiao, H. Biodegradable Polymers and Green-based Antimicrobial Packaging Materials: Amini-review. Adv. Ind. Eng. Polym. Res. 2019. [CrossRef]

209. Bourtoom, T. Factors affecting the properties of edible film prepared from mungbean proteins. Int. Food Res. J. 2010, 16, 167-180.

210. Falguera, V.; Quintero, J.P.; Jiménez, A.; Muñoz, J.A.; Ibarz, A. Edible films and coatings: Structures, active functions and trends in their use. Trends Food Sci. Technol. 2011, 22, 292-303. [CrossRef]

211. Gorrasi, G.; Bugatti, V. Edible bio-nano-hybrid coatings for food protection based on pectins and LDH-salicylate: Preparation and analysis of physical properties. Lwt Food Sci. Technol. 2016, 69, 139-145. [CrossRef]

212. Wihodo, M.; Moraru, C.I. Physical and chemical methods used to enhance the structure and mechanical properties of protein films: A review. J. Food Eng. 2013, 114, 292-302. [CrossRef]

213. Monedero, F.M.; Hambleton, A.; Talens, P.; Debeaufort, F.; Chiralt, A.; Voilley, A. Study of the retention and release of n-hexanal incorporated into soy protein isolate-lipid composite films. J. Food Eng. 2010, 100, 133-138. [CrossRef]

214. Fabra, M.J.; Talens, P.; Chiralt, A. Tensile properties and water vapor permeability of sodium caseinate films containing oleicacid-beeswax mixtures. J. Food Eng. 2008, 85, 393-400. [CrossRef]

215. Hu, C.; Chen, M.; Wang, Z. Release of Thymol, Cinnamaldehyde and Vanillin from Soy Protein Isolate Films into Olive Oil. Packag. Technol. Sci. 2012, 25, 97-106. [CrossRef]

216. Chen, M.; Wang, Z.; Hu, C.; Wang, J. Effects of Temperature on Release of Eugenol and Isoeugenol from Soy Protein Isolate Films into Simulated Fatty Food. Packag. Technol. Sci. 2012, 25, 485-492. [CrossRef] 
217. Liu, F.; Avena-Bustillos, R.J.; Chiou, B.-S.; Li, Y.; Ma, Y.; Williams, T.G.; Wood, D.F.; McHugh, T.H.; Zhong, F. Controlled-release of tea polyphenol from gelatin films incorporated with different ratios of free/nanoencapsulated tea polyphenolsin to fatty food simulants. Food Hydrocoll. 2017, 62, 212-221. [CrossRef]

218. Kashiri, M.; Cerisuelo, J.P.; Domínguez, I.; López-Carballo, G.; Hernández-Muñoz, P.; Gavara, R. Novel antimicrobial zein film for controlled release of lauroyl arginate (LAE). Food Hydrocoll. 2016, 61, 547-554. [CrossRef]

219. Calva-Estrada, S.J.; Jiménez-Fernández, M.; Lugo-Cervantes, E. Protein-Based Films: Advances in the Development of Biomaterials Applicable to Food Packaging. Food Eng. Rev. 2019, 11, 78-92. [CrossRef]

220. Atarés, L.; Chiralt, A. Essential oils as additives in biodegradable films and coatings for active food packaging. Trends Food Sci. Technol. 2016, 48, 51-62. [CrossRef]

221. Lara, H.H.; Ayala-Nuñez, N.V.; Ixtepan-Turrent, L.; Rodriguez-Padilla, C. Mode of antiviral action of silver nano particles against HIV-1. J. Nanobiotechnology 2010, 8, 1-10. [CrossRef]

222. Nocchetti, M.; Donnadio, A.; Ambrogi, V.; Andreani, P.; Bastianini, M.; Pietrella, D.; Latterini, L. Ag/Ag Clnano particle decorated layered double hydroxides: Synthesis, characterization and antimicrobial properties. J. Mater. Chem. B 2013, 1, 2383-2393. [CrossRef]

223. Dutta, R.K.; Nenavathu, B.P.; Gangishetty, M.K.; Reddy, A.V.R. Studies on antibacterial activity of ZnO nanoparticles by ROS induced lipid peroxidation. Colloids Surf. B: Biointerfaces 2012, 94, 143-150. [CrossRef]

224. Gadang, V.P.; Hettiarachchy, N.S.; Johnson, M.G.; Owens, C. Evaluation of antibacterial activity of whey protein isolate coating incorporated with nisin, grapeseed extract, malicacid, and EDTA ona Turkey frank furter system. J. Food Sci. 2008, 73, M389-M394. [CrossRef]

225. Ku, K.; Song, K.B. Physical properties of nisin-incorporated gelatin and corn zein films and antimicrobial activity against Listeria monocytogenes. J. Microbiol. Biotechnol. 2007, 17, 520-523. [PubMed]

226. Pintado, C.M.B.S.; Ferreira, M.A.S.S.; Sousa, I. Control of pathogenic and spoilage microorganisms from cheese surface by whey protein films containing malicacid, nisin and natamycin. Food Control 2010, 21, 240-246. [CrossRef]

227. Sivarooban, T.; Hettiarachchy, N.S.; Johnson, M.G. Physical and antimicrobial properties of grapeseed extract, nisin, and EDTA incorporated soy protein edible films. Food Res. Int. 2008, 41, 781-785. [CrossRef]

228. Zinoviadou, K.G.; Koutsoumanis, K.P.; Biliaderis, C.G. Physico-chemical properties of whey protein isolate films containing oregano oil and their antimicrobial action against spoilage flora of fresh beef. Meat Sci. 2009, 82, 338-345. [CrossRef] [PubMed]

229. Hoffman, K.L.; Han, I.Y.; Dawson, P.L. Antimicrobial Effects of Corn Zein Films Impregnated with Nisin, Lauric Acid, and EDTA. J. Food Prot. 2001, 64, 885-889. [CrossRef]

230. Kristo, E.; Koutsoumanis, K.P.; Biliaderis, C.G. Thermal, mechanical and water vapor barrier properties of sodium caseinate films containing antimicrobials and their inhibitory actionon Listeria monocytogenes. Food Hydrocoll. 2008, 22, 373-386. [CrossRef]

231. Pintado, C.M.B.S.; Ferreira, M.A.S.S.; Sousa, I. Properties of Whey Protein-Based Films Containing Organic Acids and Nisin to Control Listeria monocytogenes. J. Food Prot. 2009, 72, 1891-1896. [CrossRef]

232. Seacheol, M.; Krochta, J.M. Ascorbic acid-containing whey protein film coatings for control of oxidation. J. Agric. Food Chem. 2007, 55, 2964-2969.

233. Park, S.I.; Daeschel, M.A.; Zhao, Y. Functional properties of antimicrobial lysozyme-chitosan composite films. J. Food Sci. 2004, 69, M215-M221. [CrossRef]

234. Shokri, S.; Ehsani, A. Efficacy of whey protein coating incorporated with lactoperoxidase and $\alpha$-tocopherol in shelflife extension of Pike-Perch fillets during refrigeration. Lwt Food Sci. Technol. 2017, 85, 225-231. [CrossRef]

235. Al-Sahlany, S.T.G. Production of Biodegradable Film from Soy Protein and Essential Oil of Lemon Peeland Useitas Cheese Preservative. Basrah J. Agric. Sci. 2017, 30, 27-35. [CrossRef]

236. Kashiri, M.; Cerisuelo, J.P.; Domínguez, I.; López-Carballo, G.; Muriel-Gallet, V.; Gavara, R.; Hernández-Muñoz, P. Zein films and coatings as carriers and release systems of Zataria multiflora Boiss. essential oil for antimicrobial food packaging. Food Hydrocoll. 2017, 70, 260-268.

237. Alparslan, Y.; Yapıcı, H.H.; Metin, C.; Baygar, T.; Günlü, A.; Baygar, T. Quality assessment of shrimps preserved with orange leaf essential oil incorporated gelatin. Lwt Food Sci. Technol. 2016, 72, 457-466. [CrossRef] 
238. Bahram, S.; Rezaei, M.; Soltani, M.; Kamali, A.; Ojagh, S.M.; Abdollahi, M. Whey Protein Concentrate Edible Film Activated with Cinnamon Essential Oil. J. Food Process. Preserv. 2014, 38, 1251-1258. [CrossRef]

239. Bahram, S.; Rezaie, M.; Soltani, M.; Kamali, A.; Abdollahi, M.; Ahmadabad, M.K.; Nemati, M. Effect of whey Protein Concentrate Coating Cinamon Oil on Quality and ShelfLife of Refrigerated Beluga Sturegeon (Huso huso). J. Food Qual. 2016, 39, 743-749. [CrossRef]

240. Gómez-Heincke, D.; Martínez, I.; Partal, P.; Guerrero, A.; Gallegos, C. Development of antimicrobial active packaging materials based on gluten proteins. J. Sci. Food Agric. 2016, 96, 3432-3438. [CrossRef]

241. Kavas, G.; Kavas, N.; Saygili, D. The Effects of Thymeand Clove Essential Oil Fortified Edible Films on the Physical, Chemical and Microbiological Characteristics of Kashar Cheese. J. Food Qual. 2015, 38, 405-412. [CrossRef]

242. Lee, J.-H.; Won, M.; Song, K.B. Physical properties and antimicrobial activities of porcine meat and bone meal protein films containing corianderoil. Lwt Food Sci. Technol. 2015, 63, 700-705. [CrossRef]

243. Martucci, J.F.; Gende, L.B.; Neira, L.M.; Ruseckaite, R.A. Oregano and lavender essential oils as antioxidant and antimicrobial additives of biogenic gelatin films. Ind. Crop. Prod. 2015, 71, 205-213. [CrossRef]

244. Clarke, D.; Molinaro, S.; Tyuftin, A.; Bolton, D.; Fanning, S.; Kerry, J.P. Incorporation of commercially-derived antimicrobials into gelatin-based films and assessment of their antimicrobial activity and impact on physical film properties. Food Control 2016, 64, 202-211. [CrossRef]

245. Ibarguren, C.; Céliz, G.; Díaz, A.S.; Bertuzzi, M.A.; Daz, M.; Audisio, M.C. Gelatine based films added with bacteriocins and a flavonoid ester active against food-borne pathogens. Innov. Food Sci. Emerg. Technol. 2015, 28, 66-72. [CrossRef]

246. Kanmani, P.; Rhim, J.-W. Physicochemical properties of gelatin/silver nanoparticle antimicrobial composite films. Food Chem. 2014, 148, 162-169. [CrossRef] [PubMed]

247. Barbosa-Pereira, L.; Cruz, J.M.; Sendón, R.; Rodríguez Bernaldode Quirós, A.; Ares, A.; Castro-López, M.; Abad, M.J.; Maroto, J.; Paseiro-Losada, P. Development of antioxidant active films containing tocopherols to extend the shelflife of fish. Food Control 2013, 31, 236-243. [CrossRef]

248. Fabra, M.J.; Hambleton, A.; Talens, P.; Debeaufort, F.; Chiralt, A. Effect of ferulicacid and $\alpha$-tocopherol antioxidants on properties of sodium caseinate edible films. Food Hydrocoll. 2011, 25, 1441-1447. [CrossRef]

249. Jiménez, A.; Fabra, M.J.; Talens, P.; Chiralt, A. Physical properties and antioxidant capacity of starch-sodium caseinate films containing lipids. J. Food Eng. 2013, 116, 695-702. [CrossRef]

250. Benbettaïeb, N.; Chambin, O.; Assifaoui, A.; Al-Assaf, S.; Karbowiak, T.; Debeaufort, F. Release of coumarin incorporated into chitosan-gelatin irradiated films. Food Hydrocoll. 2016, 56, 266-276. [CrossRef]

251. Kaewprachu, P.; Osako, K.; Benjakul, S.; Suthiluk, P.; Rawdkuen, S. Shelflife extension for Bluefin tuna slices (Thunnus thynnus) wrapped with myofibrillar protein film incorporated with catechin-Kradon extract. Food Control 2017, 79, 333-343. [CrossRef]

252. Ciannamea, E.M.; Stefani, P.M.; Ruseckaite, R.A. Properties and antioxidant activity of soy protein concentrate films incorporated with redgrape extract processed by casting and compression molding. LWT 2016, 74, 353-362. [CrossRef]

253. Gallego, M.G.; Gordon, M.H.; Segovia, F.; Pablos, M.P.A. Gelatine-Based Antioxidant Packaging Containing Caesalpinia decapetala and Tara as a Coating for Ground Beef Patties. Antioxidants 2016, 5, 10. [CrossRef]

254. Wu, J.; Chen, S.; Ge, S.; Miao, J.; Li, J.; Zhang, Q. Preparation, properties and antioxidant activity of an active film from silver carp (Hypophthalmichthys molitrix) skin gelatin incorporated with greentea extract. Food Hydrocoll. 2013, 32, 42-51. [CrossRef]

255. Yang, H.-J.; Lee, J.-H.; Won, M.; Song, K.B. Antioxidant activities of distiller dried grains with solubles as protein films containing tea extracts and their application in the packaging of pork meat. Food Chem. 2016, 196, 174-179. [CrossRef] [PubMed]

256. Gómez-Guillén, M.C.; Ihl, M.; Bifani, V.; Silva, A.; Montero, P. Edible films made from tuna-fish gelatin with antioxidant extracts of two different murta ecotypes leaves (Ugni molinae Turcz). Food Hydrocoll. 2007, 21, 1133-1143. [CrossRef]

257. Alves-Silva, J.M.; DiasdosSantos, S.M.; Pintado, M.E.; Pérez-Álvarez, J.A.; Fernández-López, J.; Viuda-Martos, M. Chemical composition and invitro antimicrobial, antifungal and antioxidant properties of essential oils obtained from some herbs widely used in Portugal. Food Control 2013, 32, 371-378. [CrossRef] 
258. Ruiz-Navajas, Y.; Viuda-Martos, M.; Sendra, E.; Perez-Alvarez, J.A.; Fernández-López, J. In Vitro antibacterial and antioxidant properties of chitosan edible films incorporated with Thymus moroderi or Thymus piperella essential oils. Food Control 2013, 30, 386-392. [CrossRef]

259. Song, N.-B.; Lee, J.-H.; AlMijan, M.; Song, K.B. Development of a chicken feather protein film containing cloveoil and its application in smoked salmon packaging. Lwt Food Sci. Technol. 2014, 57, 453-460. [CrossRef]

260. Moradi, M.; Tajik, H.; RazaviRohani, S.M.; Mahmoudian, A. Antioxidant and antimicrobial effects of zein edible film impregnated with Zataria multiflor a Boiss. essential oil and monolaurin. Lwt Food Sci. Technol. 2016, 72, 37-43. [CrossRef]

261. Alexandre, E.M.C.; Lourenço, R.V.; Bittante, A.M.Q.B.; Moraes, I.C.F.; Sobral, P.J.D.A. Gelatin-based films reinforced with montmorillonite and activated with nanoemulsion of ginger essential oil for food packaging applications. Food Packag. Shelf Life 2016, 10, 87-96. [CrossRef]

262. MaryamAdilah, Z.A.; NurHanani, Z.A. Active packaging of fish gelatin films with Morinda citrifolia oil. Food Biosci. 2016, 16, 66-71. [CrossRef]

263. Teixeira, B.; Marques, A.; Pires, C.; Ramos, C.; Batista, I.; Saraiva, J.A.; Nunes, M.L. Characterization of fish protein films incorporated with essential oils of clove, garlic and origanum: Physical, antioxidant and antibacterial properties. Lwt Food Sci. Technol. 2014, 59, 533-539. [CrossRef]

(C) 2019 by the authors. Licensee MDPI, Basel, Switzerland. This article is an open access article distributed under the terms and conditions of the Creative Commons Attribution (CC BY) license (http://creativecommons.org/licenses/by/4.0/). 